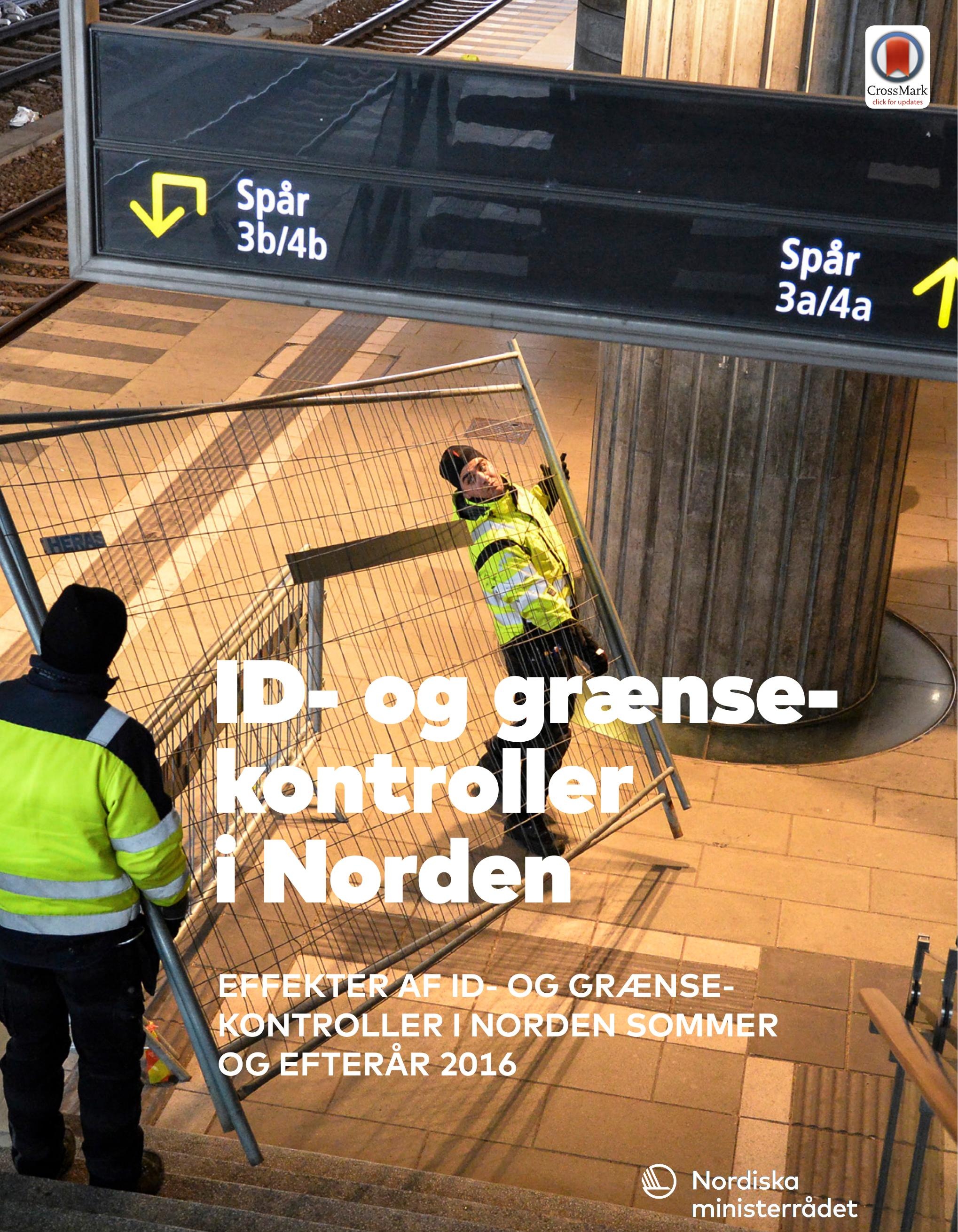





\section{ID- og grænsekontroller i Norden}

ID- og grænsekontroller i Norden sommer og efterår 2016

Britt Andresen, Anna Palmehag, Johan Wessman og Thea Wiborg

TemaNord 2016:554 


\section{ID- og grænsekontroller i Norden}

ID- og grænsekontroller i Norden sommer og efterår 2016

Britt Andresen, Anna Palmehag, Johan Wessman og Thea Wiborg

ISBN 978-92-893-4757-0 (PRINT)

ISBN 978-92-893-4758-7 (PDF)

ISBN 978-92-893-4759-4 (EPUB)

http://dx.doi.org/10.6027/TN2016-554

TemaNord 2016:554

ISSN 0908-6692

Standard: PDF/UA-1

ISO 14289-1

(c) Nordiska ministerrådet 2016

Layout: Hanne Lebech

Omslagsfoto: Scanpix

Tryck: Rosendahls-Schultz Grafisk

Printed in Denmark

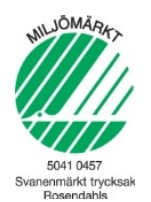

Denna rapport är utgiven med finansiellt stöd från Nordiska ministerrådet. Innehållet i rapporten avspeglar inte nödvändigtvis Nordiska ministerrådets synpunkter, åsikter eller rekommendationer

\section{Det nordiska samarbetet}

Det nordiska samarbetet är ett av världens mest omfattande regionala samarbeten. Det omfattar Danmark, Finland, Island, Norge och Sverige samt Färöarna, Grönland och Åland.

Det nordiska samarbetet är politiskt, ekonomiskt och kulturellt förankrat och en viktig del av europeiskt och internationellt samarbete. Den nordiska gemenskapen arbetar för ett starkt Norden i ett starkt Europa.

Det nordiska samarbetet ska stärka nordiska och regionala intressen och värderingar i en global omvärld. Gemensamma värderingar länderna emellan bidrar till att stärka Nordens ställning som en av världens mest innovativa och konkurrenskraftiga regioner. 


\section{Indhold}

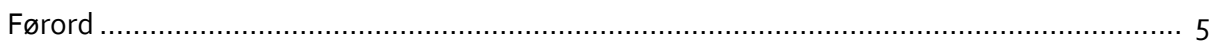

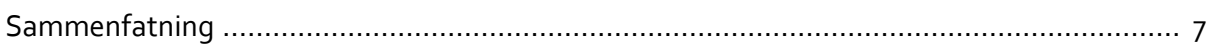

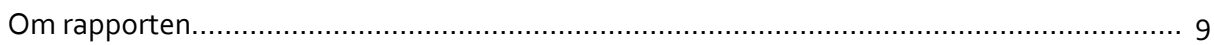

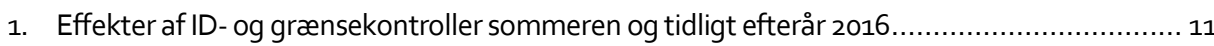

1.1 Effekter af grænse- og ID-kontroller for borgere, trafik og regional udvikling....... 11

1.2 Rättslig analys av de tillfälliga gränskontrollerna i Norden ............................... 25

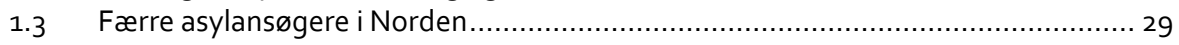

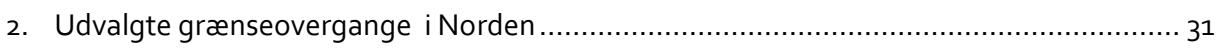

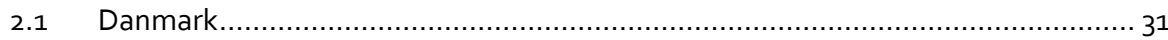

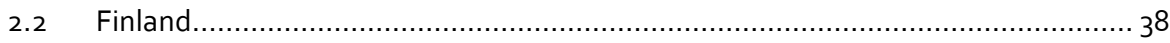

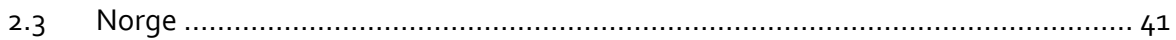

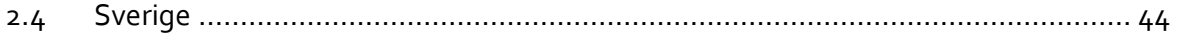

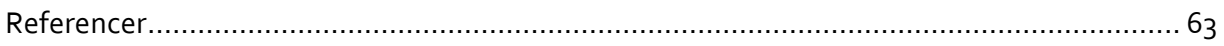

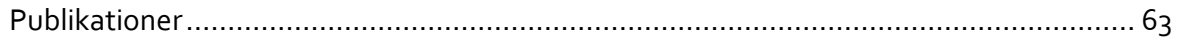

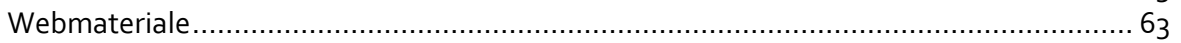

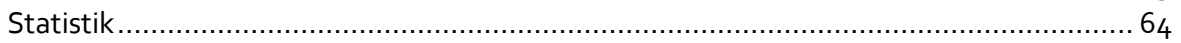

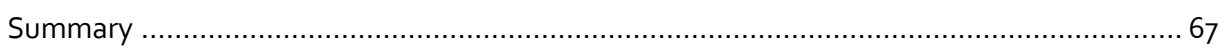

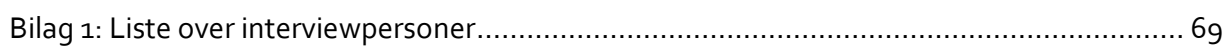





\section{Førord}

Denna rapport som överlämnades till de nordiska samarbetsministrarna den 1 november 2016 beskriver de effekter de tillfälliga id- och gränskontrollern har haft på ekonomin och mobiliteten i Norden under sommaren och hösten 2016.

Syftet med denna rapport är att följa upp rapporten ID- og grænsekontroller $i$ Norden: Effekter af ID- og grænsekontroller i et nordisk perspektiv som beskrev situationen under det första halvåret med tillfälliga id- och gränskontroller i Norden. Båda rapporterna har tagits fram av Öresundsinstituttet som ett led i det uppdrag jag har fått av samarbetsministrarna att fortlöpande analysera hur kontrollerna påverkar den fria rörligheten i Norden.

Köpenhamn, november 2016

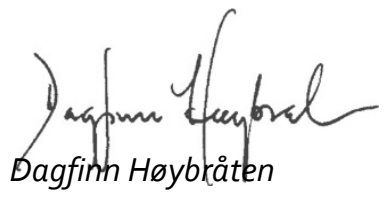

Generalsekreterare

Nordiska ministerrådet 



\section{Sammenfatning}

I løbet af efteråret og vinteren 2015/16 blev der indført grænse-, ID- og toldkontroller på de indre nordiske grænser på grund af den store mængde flygtninge, der kom til Norden. Det har påvirket den frie bevægelighed mellem de nordiske lande.

De tydeligste negative effekter af grænse- og ID-kontroller i Norden er for togrejsende over Øresund. Dette var også tilfældet i maj og juni måned 2016 under udarbejdelsen af den første rapport om effekterne af ID- og grænsekontroller Nordisk Ministerråd (2016) ID- og grænsekontroller i Norden. Effekter af ID- og grænsekontroller i et nordisk perspektiv. I løbet af sommeren har der dog også været kilometerlange køer, primært i weekenderne, ved den dansk-tyske grænse. For rederierne, der før sommeren udtrykte en vis uro for hvordan højsæsonen ville udvikle sig, har grænsekontrollen dog kun på enkelte afgange på én enkelt rute, Scandlines Gedser-Rostock, givet anledning til forsinkelser af færgedriften. På den svensk-finske og den norsk-svenske grænse er situationen uforandret i forhold til tidligere.

ID- og grænsekontrollen har ikke påvirket passagertallet på færgerne fra Tyskland til de nordiske lande eller på de fleste strækninger mellem de nordiske lande. Men Øresundstog og rederiet HH Ferries, med trafik mellem Sverige og Danmark, har haft et faldende antal rejsende og antal togrejsende mellem Tyskland og Danmark er ligeledes faldet. Især Øresundstogene har med et fald på 12 \% januar-september sammenlignet med samme periode 2015 mistet mange passagerer.

En effekt af grænse- og ID-kontrollerne for Øresundstogene er, at flere vælger toget fra og anvender bilen i stedet. Øresundsbro Konsortiet har tidligere kunnet notere flere busser, taxaer og mere erhvervstrafik på grund af grænse- og ID-kontrollerne, men fra september også flere bilpendlere. Øresundsbrons vejdel er den eneste store trafikforbindelse, der har haft høj vækst. I september passerede $7,7 \%$ flere køretøjer Øresundsbron.

En række rapporter, der er offentliggjort de seneste måneder, sætter fokus på hvordan grænse- og ID-kontroller påvirker det fælles dansk-svenske arbejdsmarked på tværs af Øresund: 
- For togrejsende er det fælles dansk-svenske arbejdsmarked minsket kraftigt. 322.000 færre arbejdspladser kan nås på én time fra Malmö C med kollektiv trafik og 193.000 færre fra Lund sammenlignet med inden ID- og grænsekontrollerne blev indført.

- Fire ud af fem af de togpendlere, der har deltaget i en spørgeskemaundersøgelse, svarer at de overvejer at søge job i hjemlandet eller flytte til arbejdslandet. 400 pendlere deltog i undersøgelsen.

- En rundspørge blandt 10 virksomheder viser, at de danske arbejdsgivere har sværere ved at fastholde og rekruttere medarbejdere fra Sverige. En del arbejdsgivere kompenserer deres ansatte, for eksempel gennem øget flextid eller leje af busser til hjemtransporten, men forventer ikke at kunne fortsætte med det i længere tid. Ikea og Sony Mobile noterer at den dårligere tilgængelighed til Københavns Lufthavn og den øgede trængsel i Øresundstogene indenrigs i Sverige er problematisk.

Der er ingen entydige effekter af ID- og grænsekontrol på turismen. Dog tyder det på, at der er en negativ effekt på antallet af overnatninger i nærområdet i Greater Copenhagen og Syddanmark. Svenske overnatninger i Region Hovedstaden er faldet 4,3\%, danske overnatninger i Skåne 5,1 \%, og tyske overnatninger i Region Syddanmark med $1,4 \%$.

Antal tilfælde hvor flygtninge og migranter sætter livet på spil for at komme over grænsen er steget. I løbet af sommeren forværredes problemet med personer, der går mod eller ned i Øresundstunnelen, men antal incidenter faldt igen i september. I perioden 4. januar til den 2. oktober har der i 135 tilfælde været personer i Øresundstunnelen eller på vej mod tunnelen i et forsøg på at gå til Sverige. Både i Göteborg og i Helsingborg sker det at politiet opdager, at flygtninge har gemt sig under lastbiler. I Helsingborg sker det regelmæssigt ifølge svensk politi.

Den praktiske udførelse af ID-kontrollerne mellem Danmark og Sverige anskueliggør ubalancen mellem borgernes ansvar for at kende til og håndtere kravet om gyldig legimitation ved indrejse til Sverige på den ene side og myndighedernes ansvar for at bistå borgerne, der ikke har gyldig ID med. Det nuværende system er ikke gearet til en situation, hvor borgerne hyppigt og med korte tidsmellemrum bevæger sig frem og tilbage over grænsen og derfor har brug for meget hurtig hjælp i de situationer, hvor behovet opstår.

Ifølge en retslig analyse vurderes de midlertidige grænsekontroller i Norden ikke at stride mod de nordiske aftaler om pasfrihed som giver nordiske borgere ret til at rejse til et andet nordisk land uden pas eller anden rejselegitimation. 


\section{Om rapporten}

Øresundsinstituttet fik i september til opgave for Nordisk Ministerråd at udarbejde en opfølgning på rapporten ID- og grænsekontroller i Norden. Effekter af ID- og grænsekontroller i et nordisk perspektiv, der blev offentliggjort juli 2016. Nærværende rapport fungerer som en opdatering til den tidligere rapport og retter fokus på udviklingen henover sommeren og det tidlige efterår 2016. Der henvises til den tidligere rapport for at få en fyldestgørende beskrivelse af udformningen af grænse- og ID-kontroller i Norden og det lovgivningsmæssige grundlag for disse.

Information til at udarbejde rapporten er indhentet ved internet-research, faktaindsamling samt 32 interviews gennemført via mail eller telefon i hele Norden. Interviewene er gennemført i løbet af september og oktober 2016.

Som i den tidligere rapport rettes fokus på 11 grænseovergange i Norden. En beskrivelse af grænsekontrollen og effekter af denne i løbet af sommeren og det tidlige efterår 2016 findes i del 2 af rapporten for hver af de 11 grænseovergange. Del 1 indeholder en sammenfatning af materialet.

Formålet med rapporten er at sætte fokus på hvilke effekter grænse- og IDkontroller har på mobiliteten, de rejsende og økonomien i de nordiske grænseregioner. I opgavebeskrivelsen indgår ikke at analysere hvorvidt kontrollerne begrænser strømmen af asylansøgere til Norden eller de regionaløkonomiske effekter som følge af dette. 



\section{Effekter af ID- og grænsekontroller sommeren og tidligt efterår 2016}

Efteråret 2015 satte med genindførelsen af midlertidig grænsekontrol punktum for mere end 50 års pasfrihed og fri bevægelighed mellem de nordiske lande. Danmark, Norge og Sverige benyttede sig af den mulighed, der findes i EU lovgivningen for at genindføre midlertidig grænsekontrol. Nu et år senere ser situationen anderledes ud. Den vestlige Balkan-rute er lukket og 6. oktober påbegyndte Det Europæiske Agentur for Grænse- og Kystbevogtning sit arbejde. Agenturet skal overvåge EU's ydre grænser og samarbejde med medlemsstaterne om at identificere og håndtere potentielle sikkerhedstrusler mod EU og Schengenområdet. EU har desuden indgået en aftale med Tyrkiet om tilbagesendelse af flygtninge. Aftalen er dog skrøbelig og samtidig ses et stigende antal flygtninge i Italien som er rejst fra den nordafrikanske kyst og som ikke kan komme længere op i Europa.

\subsection{Effekter af grænse- og ID-kontroller for borgere, trafik og regional udvikling}

Efter snart et år med grænsekontroller og mere end 9 måneder med ID-kontroller er det åbenlyst at de tydeligste negative effekter i Norden opstår for togrejsende på tværs af Øresund. Men i løbet af sommeren har der også været kilometer lange køer ved den dansk-tyske grænse, især om lørdagen, hvor der skiftes lejere i de danske sommerhuse. Kombinationen af vejarbejder på den tyske side af grænsen, der har begrænset kapaciteten på motorvejen til en vejbane og grænsekontrollen bliver givet som forklaring på de meget lange køer, der er opstået. Både for Øresundstog og den dansk-tyske grænse i sommerperioden er der tale om trafiksystemer med begrænset kapacitet, hvor tilkomsten af en ID- eller grænsekontrol sætter systemet under pres og skaber yderligere problemer i spidsbelastningsperioderne - ferieperioder for den dansk-tyske landegrænse og primært i myldretiden for Øresundstogene.

Set i et helikopterperspektiv kan det synes som om de negative effekter af ID- og grænsekontroller i Norden ikke er så store, men et fald i antal togrejsende over Øresund på $12 \%$ i perioden januar-august 2016 sammenlignet med samme periode i 
2015, når trafikselskaberne inden indførelsen af ID-kontrol forventede en trafikvækst på $5 \%$, samt at $82 \%$ af togpendlere på grund af frustration over længere rejsetid, dårligere regularitet og øget trængsel $\mathrm{i}$ togene, overvejer at søge job i hjemlandet eller flytte til arbejdslandet, vidner om en anstrengende situation i de grænseregioner, hvor de negative effekter rammer.

\subsubsection{Sommeren forløb stort set uden de frygtede problemer - men kilometerlange køer ved den dansk-tyske landegrænse $i$ spidsperioderne og stadig problemer for Øresundstog}

I rapporten Nordisk Ministerråd (2016) ID- og græensekontroller i Norden. Effekter af ID- og grænsekontroller i et nordisk perspektiv udtrykte en del rederier og andre aktører bekymring for hvordan højsæsonen ville forløbe. Bekymringen gik på, hvorvidt det var muligt at holde sejlplanen med flere rejsende, hvoraf mange ikke var vant til grænse- og IDkontrol, samt om de rejsende ville holde sig væk på grund af grænse- og ID-kontrol.

De fleste rederier som sejler mellem Tyskland og et nordisk land eller mellem de nordiske lande, oplyser at der ikke har været nogle problemer med ID- og grænsekontroller i løbet af sommeren. På rederiet Scandlines afgange mellem Gedser og Rostock har der i enkelte tilfælde været forsinkelser eftersom køer ved grænsekontrollen har forårsaget, at færgen ikke kunne tømmes i tid. Derudover oplyser rederierne at der ikke har været nogle forsinkelser, ændringer i måden at kontrollere på eller negative reaktioner fra passagererne.

For Øresundstogene forværredes situationen gradvist i løbet af første halvår med faldende regularitet måned for måned frem til juni, hvor 19 \% af togene fra Sverige til Danmark og $22 \%$ fra Danmark til Sverige var forsinkede. Regulariteten er siden blevet bedre, men ligger stadig lavt. På grund af den dårlige regularitet kører et stigende antal tog fra Sverige forbi uden at stoppe i Københavns Lufthavn til gene for de rejsende fra Sverige, der får forlænget deres rejse til Københavns Lufthavn omkring en halv time.

Siden ID-kontrollen blev indført er antallet af afgange med Øresundstoget over Øresund blevet halveret i myldretiden, så de kun afgår hvert 20. minut. DSB og Skånetrafiken tester i løbet af efteråret mulige set-ups for ID-kontrollen med det formål at få 10-minutters driften i myldretiden tilbage. Hvis testene falder positivt ud, forventes det at nye set-up vil blive implementeret ved årsskiftet. Det vil give flere tog og kortere rejsetid, hvilket vil være en stor forbedring for de togrejsende. Dog vil rejsetiden stadig være længere end inden grænse- og ID-kontrollerne blev indført.

Ved den dansk-tyske landegrænse har der på visse tidspunkter, primært om lørdagen, der er skiftedag for sommerhusturisterne, været kilometerlange køer. 


\subsubsection{Faldende antal rejsende med tog over grænserne og med færge mellem Helsingør og Helsingborg}

ID- og grænsekontrollen har ikke påvirket passagerantallet på færgerne fra Tyskland til de nordiske lande eller på de fleste strækninger mellem de nordiske lande. Men Øresundstog og HH Ferries har haft et faldende antal rejsende og antal togrejsende mellem Tyskland og Danmark er ligeledes faldet. Den eneste store trafikforbindelse, der har haft høj vækst i løbet af de seneste måneder er Øresundsbrons vejdel.

Antal rejsende med Øresundstoget over Øresundsbron mindskede i løbet af årets første otte måneder med $12 \%$, udover en udeblevet passagerstigning på $5 \%$, som Skåne trafiken og DSB havde regnet med. For SJ mindskede antallet af passagerer med $20-25 \%$ i samme periode. Såvel pendlere som privatrejsende har i alt højere grad fravalgt toget.

I stedet for er antallet af biler på Øresundsbron steget, til en vis del i sommer, men frem for alt i september, hvor stigningen på $8 \%$ var betydeligt større end i alle andre september måneder siden 2007. Øresundsbro Konsortiet har tidligere noteret at grænse- og ID-kontrollerne giver flere busser, taxaer og erhvervskørsel i personbiler, men noterer at i september er der også tale om flere pendlere.

Antal køretøjer med færgerne mellem Helsingør og Helsingborg er faldet $0,8 \%$ i perioden januar-september 2016 i forhold til samme periode 2015, men en stigning i antal overførte busser og især lastbiler, har dæmpet faldet. Antal personbiler er i samme periode faldet 2,6\%. Antal passagerer er ligeledes faldet - med 2,1\%.

Antal køretøjer på ruten Rødby-Puttgarden ligger på samme niveau 1. halvår 2016 som 1. halvår 2015, mens antal passagerer er faldet 2,3 \%. På Gedser-Rostock ruten, der er en langt mindre rute end Rødby-Puttgarden, er såvel antal køretøjer som antal passagerer steget $9 \%$ i 1. halvår 2016 sammenlignet med 1. halvår 2015, hvilket forklares ved vækst i ferieperioderne og i januar 2016.

Det samlede antal togrejsende mellem Tyskland og Danmark er faldet $10 \% \mathrm{i}$ 1. halvår 2016 sammenlignet med samme periode året for inden.

\subsubsection{Effekter på arbejds- og boligmarkedet over Øresund}

De negative effekter af grænse- og ID-kontrollen for Øresundstog mindsker det fælles arbejdsmarked i Greater Copenhagen markant. 322000 færre arbejdspladser kan nås på én time fra Malmö C med kollektiv trafik og 193000 færre fra Lund sammenlignet med inden ID- og grænsekontrollerne blev indført, viser beregninger foretaget af Øresundsinstituttet og Region Skåne.

De negative effekter på bolig- og arbejdsmarkedet giver sig også udslag i, at fire ud af fem af de togpendlere, der har deltaget i en spørgeskemaundersøgelse, svarer at 
de overvejer at søge job i hjemlandet eller flytte til arbejdslandet. Undersøgelsen blev lavet i forbindelse med den svenske Länsstyrelsen Skånes rapport "Utvärdering av effekter av tillämpningen av förordning om vissa identitetskontroller" og blev besvaret af 400 pendlere. Eftersom rundspørgen blev foretaget $i$ en diskussionsgruppe for Øresundspendlere, er der en risiko for bias i svarene, men med tanke på antallet af svar, giver det en tydelig indikation på problemets omfang.

En rundspørge blandt 10 virksomheder, som også blev foretaget i forbindelse med "Utvärdering av effekter av tillämpningen av förordning om vissa identitetskontroller", viser, at de danske arbejdsgivere har sværere ved at fastholde og rekruttere medarbejdere fra Sverige. En del af de adspurgte arbejdsgivere kompenserer deres ansatte, men forventer ikke at kunne fortsætte med det i længere tid. De to interviewede svenske virksomheder, Ikea og Sony Mobile, noterer at den dårligere tilgængelighed til Københavns Lufthavn og den øgede trængsel i Øresundstogene indenrigs i Sverige, som hænger sammen med omlægningen af togtrafikken på grund af ID- og grænsekontrol, er problematisk.

\subsubsection{Effekter for turismen}

Der er ingen entydige effekter af ID- og grænsekontrol på turismen. Dog tyder det på, at der er en negativ effekt på antallet af overnatninger i nærområdet i Greater Copenhagen og Syddanmark. I perioden januar til august 2016 sammenlignet med samme periode sidste år, er antallet af svenske overnatninger faldet med 4,3\% i Region Hovedstaden, danske overnatninger er faldet 5,1 \% i Skåne, og antallet af tyske overnatninger er faldet med 1,4 \% i Region Syddanmark. Men da mange andre ting påvirker turismen er det svært at konkludere entydigt. Blandt andet er forskellen på den svenske og den danske krone blevet større, hvilket kan påvirke et fald i antallet af svenske overnatninger i Danmark.

En spørgeskema- og interviewundersøgelse i turismebranchen i Skåne giver et billede af at antallet af danske besøgende er uforandret eller er faldet i løbet af 2016. ${ }^{1}$ Lidt mere end halvdelen af respondenterne i undersøgelsen (53 \%) tror ikke at grænsekontrollerne har ført til færre danske gæster, men de respondenter, som har oplyst at antallet danske gæster er faldet kraftigt i løbet af 2016 svarer derimod alle, at de

\footnotetext{
${ }^{1}$ Enkäten skickades ut via e-post till drygt 2100 aktörer inom den skånska besöksnäringen som finns i Tourism in Skånes register. Antalet svar är 145 stycken (svarsfrekvens 6,9\%) så resultatet bör ses som en indikation som tillsammans med övriga källor ger oss en bild av situationen, men respondentbasen är genomgående låg. Dessa enkäter kompletterades sedan med telefonintervjuer med 10 utvalda aktörer som representerar några av de största företagen inom skånsk besöksnäring.
} 
tror at det er på grund af grænse- og ID-kontrollerne. Undersøgelsen har dog en lav svarprocent og der findes derfor en risiko for at den ikke er repræsentativ.

\subsubsection{Stigende antal tunnelgængere i løbet af sommeren}

Mellan den 4 januari då id-kontrollerna infördes i Sverige och den 2 oktober har det vid 135 tillfällen hänt att människor gått i Öresundstunneln eller i Kastrup på väg mot tunneln, för att försöka ta sig till Sverige. Antalet incidenter med personer i eller nära tunneln ökade kraftigt under sommaren, då det skedde i genomsnitt 5,7 gånger per vecka, men antalet minskade igen under september, uppger Øresundsbro Konsortiet. När det finns gående i tunneln stoppas all trafik för att förhindra olyckor. Än har dock ingen olycka skett.

Såväl i Göteborg som i Helsingborg händer det att polisen upptäcker att flyktingar gömt sig under lastbilar. I Helsingborg sker det regelbundet, uppger polisen. Därför samverkar polis, tull, rederier och lastbilsföretag för att kontrollera lastbilarna och därmed minska risken för svåra olyckor.

Vid den dansk-tyska gränsen har det under sommaren inträffat några trafikolyckor där bilisten har missat att det varit kö på motorvägen på grund av gränskontrollen.

\subsubsection{Stark kritik av gräns- och id-kontroller}

Efter genomgång av debattforum och media kan kritiken mot kontrollerna delas upp i tre kategorier, där den första gäller den politiska bedömningen och därför ligger utanför denna analys:

1. Politiska synpunkter på att det utförs gränskontroller inom Norden/EU samt synpunkter på flyktingmottagning, flyktingars rättigheter och mänskliga rättigheter.

2. Den utökade restiden, ökad trängsel och ökad frekvens av förseningar vid tågresor över Öresund.

3. Personer hemmahörande i Norden som inte släpps in i Sverige igen på grund av att personen ej haft med sig giltig legitimation. 


\subsubsection{Strikta kontroller begränsar mobiliteten för nordbor}

\section{Gränskontroller}

Enligt en rättslig analys gjord av Nordiska ministerrådet bedöms de tillfälliga gränskontrollerna i Norden inte strida mot de avtal som reglerar den nordiska passfriheten. Det protokoll från 1954 som ger nordiska medborgare rätt att resa till ett annat nordiskt land utan pass eller annan reselegitimationshandling innehåller undantagsregler som borde vara i linje med de krav som ställs för att införa tillfälliga gränskontroller enligt Schengenkoden. Därtill har passkontrollöverenskommelsen från 1954 som avskaffar gränskontrollerna i Norden anpassats till de nordiska ländernas deltagande i Schengensamarbetet och reglerna om tillfälliga gränskontroller.

Enligt EU:s direktiv om fri rörlighet har EU/EES-medborgare rätt att passera tillfälliga gränskontroller med giltigt id-kort eller pass. Direktivet utgör därmed ett hinder mot tillfälliga gränskontroller där endast pass godtas. Vid samtliga gränskontroller som har införts internt i Norden godtas nationella id-kort. Enligt EU-reglerna har den som saknar giltigt id-kort eller pass dessutom rätt att på annat sätt visa att denne har rätt att passera gränskontrollen. Därmed ska även andra handlingar och omständigheterna i övrigt kunna beaktas i bedömningen om en person har rätt att passera kontrollen.

Vid inresa från Danmark till Sverige betraktas körkort som giltig id-handling och det gäller även vid inresa till Norge. ${ }^{2}$ Enligt uppgift från Polisen i Norge kan även bankkort med bild och födelsedatum användas till att styrka sitt nordiska medborgarskap, men polisen rekommenderar att även nordiska medborgare tar med pass på resan.

\section{Id-kontroller}

Transportörernas id-kontroller är som regel mer strikta än myndigheternas gränskontroller, eftersom det i gränskontrollerna finns möjlighet att verifiera en nordbos identitet på andra sätt än genom en giltig id-handling.

Transportörerna kör en strikt linje för att inte få böter. Till exempel har HH Ferries som trafikerar färjerutten Helsingör-Helsingborg under perioden januari till september utfört 2,6 miljoner id-kontroller i Helsingör. Vid dessa kontroller har 8600 personer avvisats på grund av att de saknat giltiga id-handlingar. Av dessa personer bedöms $2 \%$, motsvarande 176 personer, vara potentiella asylsökande. Den största delen av dem som avvisats är nordiska medborgare som glömt id-handlingarna eller har ogiltiga sådana. HH-Ferries har erbjudit svensk polis en lokal i Helsingör för att på plats kunna göra en myndighetsbedömning av personer som saknar godkänd id-

2 Ved den dansk-tyske grænse må danskerne have passet med sig, da der i dag ikke er et nationalt ID-kort i Danmark og da kørekort ikke accepteres som gyldigt ID på samme måde som ved ID- og grænsekontrol mellem Danmark og Sverige. 
handling. Då skulle HH-Ferries kunna få en garanti om att de kan transportera den aktuella personen till Sverige utan risk för att behöva betala böter på 50 ooo SEK.

Regelbundet rapporteras det om hur personer på grund av olika omständigheter drabbats av uppenbara olägenheter på grund av att de inte känt till de krav som ställs vid id-kontrollerna eller att de av andra skäl inte kunnat legitimera sig. Med tillgång till modern bild- och videoöverföringsteknik borde det vara möjligt för svensk polis att via en "het linje" och en dygnet-runt-bemannad telefoncentral kunna säkerställa identiteten på personer som saknar godkänd id-handling. En sådan het linje skulle minska de negativa följdverkningarna för många tågresenärer över Öresund. I den negativa vågskålen finns de ökade kostnader som en het linje skulle medföra samt risken för att en sådan skulle minska resenärernas incitament att ta med sig godkänd id-handling vid resa mellan Danmark och Sverige.

Exempel på tillfällen då en "het linje"skulle lösa problemen smidigt är:

- Nyligen rapporterade lokala svenska medier om ett fotbollslag som skulle flyga till Ängelholm för att spela en match. Men flygningen blev inställd och laget insåg då att de inte som tidigare kunde välja en alternativ flygrutt till Köpenhamn eftersom vissa spelare inte hade godkänd legitimation med sig, då de hade räknat med att flyga inrikes.

- Ett annat exempel som media rapporterat om gällde en rullstolsbunden 92-åring vars körkort nyligen löpt ut. Personen nekades hemresa med färja till Helsingborg och anhöriga tvingades köra till Helsingör för att hämta honom och sedan åka hem via bron där polisen som skötte den inre gränskontrollen hade tillgång till passregistret och därmed kunde verifiera personens identitet.

- Med jämna mellanrum skriver tågpendlare i Facebook-grupper för pendlare att de glömt sina giltiga id-handlingar. Några väntar på att en anhörig kan ta sig till Köpenhamns flygplats med id-handlingen, andra försöker få skjuts med personer som pendlar i bil och ytterligare några väljer att ta taxi till Sverige över Öresundsbron.

- En stor grupp unga norrmän på väg hem från Roskildefestivalen var övertygade om att det räckte med ett bankkort för att få resa med buss från Danmark, via Sverige, till Norge. De avvisades av bussbolaget och blev tvungna att tillbringa en extra natt i Köpenhamn. Som svar på kritiken säger bussbolaget till norska medier att de utöver böter riskerar att mista sitt tillstånd för att bedriva busstrafik. De anser därför att de inte har något annat val i en sådan situation än att avvisa passagerarna. 
Ovanstående exempler belyser en obalans mellan medborgarnas ansvar för att känna till och hantera kravet på giltig legitimation vid inresa till Sverige och myndigheternas ansvar för att bistå medborgare som av någon anledning inte har haft giltig idhandling med sig. Av exemplet med fotbollslaget framgår det att bristande tillgång till id-handlingar inte behöver bero på personlig felhantering utan på andra omständigheter som personen inte råder över.

\subsubsection{Prognoserne for asylansøgere er nedjusteret kraftigt}

Prognoserne for antallet af flygtninge og migranter, der kommer til Europa og til Norden er nedskrevet markant i forhold til tidligere på året og det faktiske antal asylansøgere er ligeledes faldet markant. I løbet af de første ni måneder af 2016 har Finland, Norge og Sverige modtaget mellem 69 og $84 \%$ færre asylansøgere end samme periode sidste år, Danmark $29 \%$ færre, mens Island har noteret en stigende asylstrøm i løbet af 2016. Det faldende antal flygtninge og migranter afspejles i hvor mange potentielle asylansøgere, der afvises ved ID-kontrollen ved den dansk-svenske grænse som nævnt ovenfor.

\subsubsection{Förslag på praktiska lösningar för att minska kontrollernas påverkan på restid och trängsel för Öresundståg - ännu inga beslut}

- Ett tidigt svenskt förslag om att samordna den tillfälliga inre svenska gränskontrollen vid tågstationen $\mathrm{i}$ Hyllie med id-kontrollen vid tågstationen vid Köpenhamns flygplats i Kastrup har inte resulterat i några framsteg som kommunicerats utåt. Danmarks justitieminister Søren Pind har tidigare uppgivit att frågan om att stationera svensk polis på dansk mark måste stämmas av mot dansk grundlag.

- Förslag från pendlare om att utföra den tillfälliga inre svenska gränskontrollen under tågresan från Danmark men efter passerandet av gränsen till Sverige har inte heller resulterat i några besked från officiellt håll.

- Förslag från den danska framtidsforskaren Uffe Palludan om att sätta in bussar i skytteltrafik under rusningstid som komplement till tågtrafiken över Öresund har inte heller resulterat i några besked från officiellt håll.

- DSB i samarbete med Banedanmark och Köpenhamns flygplats genomför just nu försök med en bättre utformning av id-kontrollen på Kastrup, vilket skulle innebära att passagerarna inte behöver byta perrong och att restiden med tåg mellan Danmark och Sverige kan minska samtidigt som kapaciteten på stationen $\mathrm{i}$ 
Kastrup utnyttjas bättre. Enligt Skånetrafiken är målet att införa det nya systemet för id-kontrollerna på Kastrup omkring nyår och att man då kan återinföra trafik med 10 minuter mellan avgångarna i rusningstid. I dagsläget avgår

Öresundstågen var 20:e minut även under rusningstid, vilket nästan halverat kapaciteten för resor över Öresund i rusningstid.

\section{FAKTA - Tidslinje}

August 2015

Norge tager imod mere end dobbelt så mange asylansøgere som samme måned året forinden. I alt 2.330 søger asyl i Norge i august 2015.

\section{September 2015}

Asylstrømmen til Sverige mere end fordobles i forhold til samme måned året forinden. Sverige tager imod i alt 24.260 asylansøgere i september 2015

Antal asylansøgere i Finland næsten firedobles på én måned til det hidtidigt højeste niveau 10.815. Finland etablerer en såkaldt flygtningesluse (ankomstcenter for kontrol af nyankomne asylansøgere).

- 8. september - Sverige definerer de kraftigt stigende flygtningestrømme som en "nationell, särskild händelse" Alma, hvor politiet arbejder med en offensiv og fremskudt, indre udlændingekontrol, dvs. kontrol af personer som lige har passeret grænsen for at fastslå om de har ret til at opholde sig i Sverige.

- 22. september-29. februar 2016 - Det finske politi, toldvæsen og grænseovervågningsvæsen intensiverer sin indsats på grænsen til Sverige

- 22. september - Norge intensiverer territorialkontrollen, der er en udlændingekontrol og kan foregå i hele landet.

Oktober 2015

Danmark modtager dobbelt så mange asylansøgere (3.635) som samme måned året forinden. Asylstrømmen til Sverige stiger til rekordniveauet 39.055 asylsøgere på én måned.

Norge modtager det hidtil største antal asylansøgninger på én måned, 8660 . Næsten dobbelt så mange som måneden før.

November 2015

Asylstrømmen til Danmark topper med 5.030 asylansøgere på en måned.

- 12. november - Sverige indfører midlertidig grænsekontrol.

- 12. november - De indenrigs rejsende i Skåne påvirkes af grænsekontrollerne. Alle tog fra Simrishamn, Ystad og Trelleborg kører ikke længere via Citytunnelen og dermed til Hyllie og Trianglen Station, men ledes via kontinentalbanen direkte til Malmö C på grund af grænsekontrollen på Hyllie Station.

- 12. november - Stena Line indfører fuldstændig ID-kontrol på sine færger til Sverige.

- 21. november - Sverige indfører krav om fuldstændig ID-kontrol på færgeruter fra Tyskland og Danmark, der er længere end 20 sømil. 
- 26. november - Norge indfører midlertidig grænsekontrol og krav på fuldstændig ID- og visumkontrol på færgerne fra Danmark, Sverige og Tyskland.

December 2015

- $\quad$ 11. december - Det danske folketing vedtager gennem en hastebehandling en lovændring (L74) der gør det muligt for regeringen at indføre transportøransvar i forbindelse med midlertidig grænsekontrol.

- 18. december - Den svenske riksdag vedtager Lag (2015:1073) om särskilda åtgärder vid allvarlig fara för den allmänna ordningen eller den inre säkerheten i landet, der giver den svenske regering mulighed for at indføre transportøransvar. Loven gælder fra 21. december 2015 og tre år frem. Samtidigt indføres transportøransvar på tog og busser fra Danmark med SFS 2015:1074 Förordning om vissa identitetskontroller vid allvarlig fara för den allmänna ordningen eller den inre säkerheten i landet.

- Ultimo december - Visumkontrol af personer fra lande hvorfra der kræves visum ved indrejse i Finland på færgeruten Travemünde- Helsingfors.

\section{Januar 2016}

- 4. januar- Transportøransvaret og dermed ID- kontrol for tog, busser og færge fra Danmark til Sverige træder i kraft.

- 4. januar - Danmark indfører midlertidig grænsekontrol med stikprøver på grænsen mellem Tyskland og Danmark.

- 4. januar - SJ indstiller alle 5 daglige afgange fra København og DSB indstiller Bornholmertoget på grund af ID-kontrollen.

- 4. januar - Tog fra Simrishamn, Ystad og Trelleborg kan igen køre til Hyllie og videre gennem Citytunnelen til Malmö C, da der er opsat et stakit på Hyllie station, der skiller indenrigsrejsende fra de rejsende, der ankommer fra Danmark.

\section{Februar 2016}

- 17. februar - Skånetrafiken sender rabatkupon på 500 svenske kroner til pendlere med månedskort til rejser over Øresund. Kuponen kan benyttes ved fornyelse af månedskortet. Status i maj er at $72 \%$ af pendlerne har udnyttet rabatten på 500 kroner.

- 19. februar - Den särskilda händelsen Alma i Sverige overgår til det ordinære politiarbejde.

- 29. februar - Den effektiviserede toldkontrol ved grænseovergangene fra Sverige til Finland afskaffes.

\section{Marts 2016}

- 1. marts-SJ genoptager afgangene fra København, da der er fundet en løsning, med ID-kontrol på Københavns Hovedbanegård og hvor togene ikke stoppe i Københavns Lufthavn. Rejsetiden mellem Københavns Hovedbanegård og Malmö C forlænges med op til 25 minutter.

- 1. marts - Tysk politi meddeler, at de sætter flere advarselsskilte op på motorvej A7 mod Danmark, der gør bilisterne opmærksomme på at der kan være kø ved grænsekontrollen. Samtidigt nedsættes hastigheden de sidste kilometer, først til $100 \mathrm{~km} / \mathrm{t}$ dernæst til $80 \mathrm{~km} / \mathrm{t}$. Det sker efter 
flere uheld, hvoraf en dødsulykke.

- 2. marts - møde mellem de nordiske integrationsministre om migrations- og flygtningespørgsmålet.

- 15. marts - DSB genoptager trafikken med Bornholmertogene, som afgår fra København H via Øresundsbron til Ystad, hvor passagerer fortsætter med færgen.

April 2016

- 10. april - Finland indfører øget kontrol og trafikbegrænsning ved grænsen til Rusland, i Salla og Raja-Jooseppi.

- 12. april - DSB dropper fotograferingen af de rejsendes ID-papirer ved ID-kontrollen i Københavns lufthavn.

- 14. april - Den svenske regering beslutter formelt at ændre forordningen om transportøransvar, så børn som rejser i grupper med en ansvarlig voksen, for eksempel lærer eller foreningsleder, undtages fra kravet om ID-papirer. Noget som uformelt har været gældende siden januar.

- 26. april - Det besluttes at Hjemmeværnet skal hjælpe politiet med den midlertidige grænsekontrol ved de danske grænseovergange til Tyskland.

Maj 2016

- 2. maj-flere EU-lande, deriblandt Sverige og Danmark, opfordrer EU-Kommissionen til at anmode Rådet om at vedtage en henstilling om at midlertidigt opretholde grænsekontrol ved de indre grænser.

- 9. maj - Ny køreplan for Øresundstog på strækningen Hyllie - Malmö C introduceres, hvilket giver de togrejsende et bedre overblik over deres rejse, da forsinkelserne i Hyllie på grund af grænsekontrollen og ventetiden i Malmö C på næste ordinære afgang nu er køreplanlagt.

- 12. maj-Rådet henstiller til Danmark, Norge, Sverige, Tyskland og Østrig at opretholde forholdsmæssig midlertidig grænsekontrol i en periode på højst seks måneder.

Juni 2016

- 2. juni - Den svenske grænsekontrol forlænges med seks måneder til og med den 11. november og den danske frem til den 12. november.

- 8. juni - Den svenske Riksdag vedtager lovændring af loven 2015:1073 särskilda åtgärder vid allvarlig fara för den allmänna ordningen eller den inre säkerheten i landet" (om ID-kontrol) som indebærer at karenstiden på to uger borttages således at regeringen kan forlænge forskrifter for transportøransvaret. Ændringen træder i kraft 1. juli.

- 9. juni - Den svenske regering giver Länsstyrelserne og andre berørte myndigheder i opdrag at evaluere effekterne af ID-kontrollerne

- 10. juni-Den norske grænsekontrol forlænges frem til den 11. november 2016.

- 13. juni-Hjemmeværnet bistår dansk politi med grænsekontrolopgaven.

Juli/august 2016

Lange køer på motorvejen ved den dansk-tyske grænse, primært i weekenderne. 


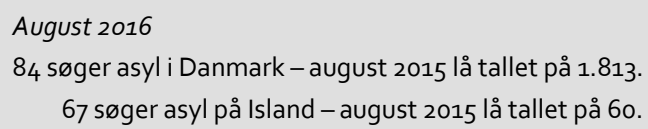

- 22. september - DSB og Skånetrafiken tester for første gang nyt set-up for ID-kontrollen i Københavns Lufthavn. Passagererne på et tog med ankomst til lufthavnen omkring midnatstid sættes af på spor 1, hvor toget til Sverige også afgår fra.

- 23. september - Den svenske regering modtager svar fra de myndigheder de har givet opdrag om at evaluere effekterne af ID-kontrollerne.

\section{September/oktober 2016}

Politiet genindfører en 12 dage lang midlertidig, men total, grænsekontrol på Tysklandsterminalen i Gøteborg havn.

\section{Oktober 2016}

- 4. oktober-DSB tester i eftermiddagsmyldretiden et muligt scenarie for passagerflow på stationen i Københavns Lufthavn med tanke på at man skal kunne håndtere al trafik mod Sverige på ét spor. Der vil blive gennemført flere tests i løbet af oktober.

- 6. oktober - Det Europæiske Agentur for Grænse- og Kystbevogtning bliver juridisk operationelt og påbegynder officielt sit arbejde.

- 6. oktober-Finlands trafikbegrænsning ved grænsen til Rusland, i Salla og Raja-Jooseppi, afsluttes.

\section{November 2016}

- 3. november - en eventuel forlængelse af transportøransvaret fra Danmark til Sverige, IDkontrollerne, skal ske senest denne dag, der er sidste dag i den nuværende periode med IDkontrol

- 10. november - en eventuel forlængelse af den norske grænsekontrol skal ske senest denne dag, der er sidste dag i den nuværende periode med grænsekontrol

- 11. november - en eventuel forlængelse af den danske og svenske grænsekontrol skal ske senest denne dag, der er sidste dag i den nuværende periode med grænsekontrol

\section{December 2016}

Senest i december 2016 får det Europæiske Agentur for Grænse- og Kystbevogtning 50 nye medarbejdere.

- 7. december - Det Europæiske Agentur for Grænse- og Kystbevogtnings udrykningsstyrke og udstyrspulje bliver operationelle. 
Januar 2017

- 7. januar - Det Europæiske Agentur for Grænse- og Kystbevogtnings tilbagesendelsesstyrker bliver operationelle.

\section{Typer af kontrol}

I denne og den tidligere rapport beskrives i alt seks forskellige slags kontroller, der kort beskrives nedenfor.

- Ydre grænsekontrol - kontroller ved lande med en ydre Schengengrænse. Kontrollen udføres af myndighedspersonale af rejsende ved ankomst til landet.

- Indre grænsekontrol - kontroller ved grænser mellem lande inden for Schengenområdet. De udføres af myndighedspersonale af rejsende ved ankomst til landet. Hvis intet andet er angivet i rapporten menes der med grænsekontrol den indre grænsekontrol.

- Visumkontrol - udføres af myndighedspersonale/transportører for rejsende fra lande med visumkrav inden eller ved ankomst til landet.

- ID-kontrol - lovgivning om transportøransvar indebærer at transportvirksomheden har pligt til at kontrollere at de rejsende har pas eller ID-papirer, der er godkendt af myndighederne i ankomstlandet, inden de forlader afrejselandet. Dette indebærer at et land beslutter en kontrol som skal udføres i nabolandet. Transportøransvaret fandtes allerede tidligere på færgeruter over 20 sømil. ID-kontrollen udføres af transportøren eller af et selskab som transportøren har sat på opgaven. I rapporten menes lovgivningen om transportøransvar når vi anvender begrebet IDkontrol.

- Intensiveret territorialkontrol - ikke en grænsekontrol, men en udlændingekontrol, der udføres af politiet. Territorialkontrollen kan ske i hele landet. Politiet kan standse en person og kræve legitimation, når der er grund til at antage at vedkommende er udenlandsk statsborger, og tid, sted og situation giver grund til sådan kontrol.

- Effektiv toldkontrol - udføres af toldere ved grænsen. 
Figur 1: Kort over Norden - her er der ID- og grænsekontrol

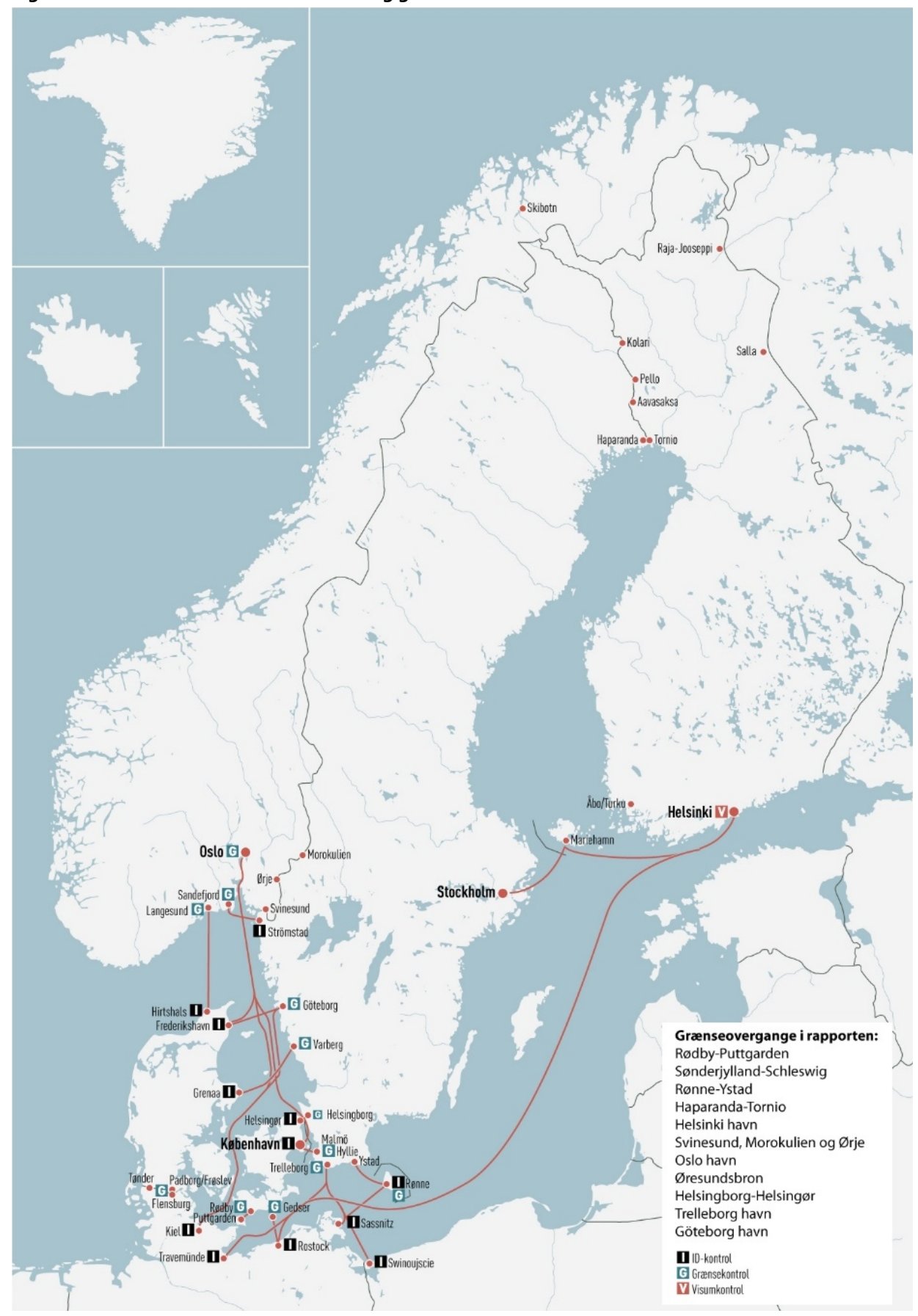




\subsection{Rättslig analys av de tillfälliga gränskontrollerna i Norden³}

\subsubsection{Sammanfattning}

- De tillfälliga gränskontrollerna i Norden bedöms inte strida mot de avtal som reglerar den nordiska passfriheten. Det protokoll från 1954 som ger nordiska medborgare rätt att resa till ett annat nordiskt land utan pass eller annan reselegitimationshandling innehåller undantagsregler som borde vara i linje med de krav som ställs för att införa tillfälliga gränskontroller enligt Schengenkoden. Passkontrollöverenskommelsen från 1954 som avskaffar gränskontrollerna i Norden har anpassats till de nordiska ländernas deltagande i Schengensamarbetet och reglerna om tillfälliga gränskontroller.

- Enligt EU:s direktiv om fri rörlighet har EU/EES-medborgare rätt att passera tillfälliga gränskontroller med giltigt id-kort eller pass. Direktivet utgör därmed ett hinder mot tillfälliga gränskontroller där endast pass godtas.

- Enligt EU:s direktiv om fri rörlighet ska vid behov andra handlingar än pass och giltigt id-kort beaktas och övriga omständigheter vägas in vid bedömningen om en EU/ESS-medborgare har rätt att passera en tillfällig gränskontroll.

- Ett antal individer har begärt skadestånd hos Justitiekanslern i Sverige på grund av de id-kontroller transportörer utför enligt svensk lagstiftning och anfört att de är olagliga. Justitiekanslern har i nuläget inte fattat beslut i något sådant ärende.

\subsubsection{Gränskontroller}

\section{Relevanta regler}

Den nordiska passfriheten följer av två olika avtal, 1954 års protokoll angående befrielse för medborgare i Sverige, Danmark, Finland och Norge från att under uppehåll i annat nordiskt land än hemlandet innehava pass och uppehållstillstånd (passfrihetsprotokollet) och 1957 års överenskommelse mellan Sverige, Danmark, Finland, och Norge om upphävande av passkontrollen vid de internordiska gränserna (passkontrollöverenskommelsen). Island har anslutit sig till både protokollet och överenskommelsen.

3 Denna del av rapporten är baserad på notatet Rättslig analys av de tillfälliga gränskontrollerna i Norden, upprättat av Nordiska Ministerrådets sekretariat. 
Enligt passfrihetsprotokollet ska nordiska medborgare kunna resa till ett annat nordiskt land utan pass eller annan reselegitimationshandling. Enligt passkontrollöverenskommelsen har passkontroller mellan de nordiska länderna upphävts.

Enligt artikel 28 i Helsingforsavtalet från 1962 ska de nordiska länderna söka bevara och ytterligare utveckla det samarbete som lett till att deras territorier utgör ett passkontrollområde. Det framgår av artikeln att kontrollen av resande, som passerar gräns mellan nordiska länder, även i övrigt skall förenklas och samordnas.

Den fria rörligheten för personer inom EU infördes 1992 genom Maastrichtfördraget och följer av artikel 3.2 i EU-fördraget och artikel 21 i Fördraget om EU:s funktionssätt (FEUF). EU-direktiv 2004/38 om fri rörlighet reglerar EU-medborgares utövande av rätten att fritt röra sig och uppehålla sig inom medlemsstaternas territorium. Direktivet är bindande för de nordiska EU-medlemmarna och gäller för Island och Norge genom EES-avtalet.

För de nordiska EU-medlemmarna följer av EU-domstolens praxis att EUlagstiftning har företräde framför avtal de har slutit sinsemellan. Detta gäller bl.a. de avtal som reglerar det nordiska samarbetet. Avtal som EU-medlemmarna har slutit med länder utanför EU innan de blev medlemmar ska enligt artikel 351 FEUF inte påverkas av EU-rätten, men de är å andra sidan skyldiga att undanröja motstridigheter mellan avtalen och EU-rätten. För EES-länderna Norge och Island följer av artikel $120 \mathrm{i}$ EES-avtalet att dess bestämmelser som huvudregel har företräde framför andra internationella avtal som medlemsländerna har förbundit sig till på samma område.

Schengensamarbetet är ett fördjupat samarbete inom ramen för EU-samarbetet som har till syfte att förverkliga den fria rörligheten genom att avskaffa gränskontroller mellan de länder som deltar i samarbetet. Schengensamarbetet bygger på 1985 års Schengenavtal och 1990 års Schengenkonvention som genomför avtalet. Sedan Schengensamarbetet integrerades i EU:s rättsliga ramverk genom Amsterdamfördraget år 1999 har delar av konventionen ersatts av EU-lagstiftning. Frågan om gränskontroller inom Schengenområdet regleras numera i EU-förordning 2016/399 (Schengenkoden).

År 1996 anslöt sig de nordiska länderna till Schengenavtalet och de inträdde i samarbetet år 2001. Till följd av de nordiska ländernas inträde i Schengensamarbetet slöt länderna år 2000 en överenskommelse om vissa tillägg till den nordiska passkontrollöverenskommelsen för att möjliggöra de nordiska ländernas deltagande i Schengensamarbetet.

Närmare om regelverket om tillfälliga gränskontroller

Enligt det nordiska passfrihetsprotokollet kan regeringarna återinföra krav på pass eller reselegitimationshandling för nordiska medborgare bl.a. i händelse av krig eller 
krigsfara eller om liknande utomordentliga internationella eller nationella förhållanden gör det påkallat.

Enligt artikel 8, 1 st. i den nordiska passkontrollöverenskommelsen kan länderna tillfälligt återinföra passkontroller mot annat nordiskt land för att förhindra omfattande illegala inresor på grund av skillnader i ländernas viseringsregler.

Artikel 2.i) i tilläggsöverenskommelsen till passkontrollöverenskommelsen innehåller en bestämmelse med innebörden att tillfälliga gränskontroller enligt Schengensamarbetets regelverk endast kan företas under en begränsad tid om annat inte följer av artikel 8, 1 st.

Enligt artikel 2. I) ska bestämmelserna i passkontrollöverenskommelsen tolkas i överensstämmelse med relevanta regler som utfärdats med anledning av Schengenkonventionen och en vidareutveckling därav.

Enligt artikel 25 et seq i Schengenkoden kan en medlemsstat besluta att tillfälligt återinföra gränskontroller inom Schengenområdet på grund av hot mot allmän ordning eller inre säkerhet.

Vid tillfälliga gränskontroller enligt Schengenkoden ska kontroller av EU/EESmedborgare göras enligt EU-direktivet om fri rörlighet. Detta följer av artikel $8.6 \mathrm{i}$ Schengenkoden.

Enligt artikel 5.1 i EU-direktivet om fri rörlighet har EU/EES-medborgare rätt att resa in på en annan medlemsstats territorium under förutsättningen att de kan uppvisa giltigt id-kort eller pass. Enligt artikel 5.4 i direktivet ska den som inte har ett giltigt id-kort eller pass ges möjlighet att på annat sätt få bekräftat eller bevisat att denne har rätt till fri rörlighet inom EU/EES-området.

Analys

Tillfälliga gränskontroller enligt Schengenkoden har förekommit i Norden sedan november 2015. I nuläget har Norge, Sverige och Danmark beslutat att upprätthålla tillfälliga gränskontroller enligt Schengenkodens artikel 29 till och med den 12 november 2016. Besluten har fattats till följd av ett beslut av Europeiska unionens råd om att rekommendera Österrike, Tyskland, Danmark, Sverige och Norge att införa tillfälliga gränskontroller på grund av exceptionella omständigheter som utgör en risk för det övergripande funktionssättet för Schengenområdet.

Vid de tillfälliga gränskontrollerna kan den som korsar gränsen mellan två nordiska länder behöva visa giltigt id-kort eller pass.

- Hur förhåller sig de tillfälliga gränskontrollerna till den nordiska passfriheten? 
Den nordiska passfriheten utgörs av rätten för nordiska medborgare att resa till ett annat nordiskt land utan pass eller annan reselegitimationshandling enligt passfrihetsprotokollet och avskaffade passkontroller mellan de nordiska länderna enligt passkontrollöverenskommelsen.

Passfrihetsprotokollet och passfrihetsöverenskommelsen ger länderna möjlighet att göra undantag från nordiska medborgares passfrihet och avskaffandet av passkontrollerna.

De skäl som anges i passfrihetsprotokollet, dvs. krig eller krigsfara eller liknande utomordentliga internationella eller nationella förhållanden, borde omfatta de villkor om hot mot allmän ordning eller inre säkerhet som krävs för att införa tillfälliga gränskontroller enligt Schengenkoden.

Enligt artikel 8, 1 st. i passkontrollöverenskommelsen kan länderna tillfälligt återinföra passkontroller mot annat nordiskt land för att förhindra omfattande illegala inresor på grund av skillnader i ländernas viseringsregler. Sedan de nordiska ländernas inträde i Schengensamarbetet innehåller passkontrollöverenskommelsen också en direkt referens till Schengenregelverkets bestämmelser om tillfälliga gränskontroller i artikel 2 i) i tilläggsöverenskommelsen. Enligt artikel 2 I) i tilläggsöverenskommelsen ska passkontrollöverenskommelsen dessutom tolkas i överensstämmelse med Schengenkonventionen och dess vidareutveckling, dvs. Schengenkoden.

De tillfälliga gränskontroller som de nordiska länderna har infört med stöd av Schengenkoden bedöms därmed inte strida mot de nordiska avtal som ligger till grund för den nordiska passfriheten.

- Kan resande i Norden avkrävas pass i tillfällig gränskontroll?

Eftersom det följer av EU-direktivet om fri rörlighet att EU/EES-medborgare har rätt att korsa en gräns i Norden med giltigt id-kort eller pass är de nordiska länderna enligt EU-lagstiftningen förhindrade att kräva att EU/EES-medborgare ska uppvisa pass i tillfälliga gränskontroller. Myndigheterna ska dessutom visa en viss flexibilitet mot den som inte kan uppvisa giltigt id-kort eller pass (se följande avsnitt). EUlagstiftningen utgör därmed i praktiken ett hinder mot tillfälliga gränskontroller i Norden där endast pass godtas. EU-reglerna hindrar dock inte passkontroller av personer som inte är EU/EES-medborgare.

- Kan resande i Norden passera tillfällig gränskontroll utan giltigt id-kort eller pass?

Enligt EU-direktivet om fri rörlighet är rätten att korsa en gräns inom EU/EES-området $\mathrm{i}$ princip förknippad med ett giltigt id-kort eller pass. Enligt artikel 5.4 i direktivet ska den 
som inte har ett giltigt id-kort eller pass dock ges möjlighet att på annat sätt få bekräftat eller bevisat att denne har rätt till fri rörlighet inom EU/EES-området. Det är upp till den nationella myndigheten att bedöma om så är fallet. Den nationella myndigheten har därmed möjlighet att beakta t.ex. körkort eller andra handlingar och även se till övriga omständigheter i sin bedömning av om personen i fråga har rätt att korsa gränsen.

\subsubsection{ID-kontrollerna och transportörsansvaret}

Sverige och Norge har genom nationell lagstiftning infört ansvar för transportörer att kontrollera att deras passagerare har giltig legitimation. Sverige har infört kontroller vid resor från Danmark och Norge har infört kontroller vid resor från Danmark och Tyskland. I Finland har inte något generellt transportörsansvar införts, men transportörerna kan på eget initiativ genomföra kontroller av sjösäkerhetsskäl och de kan vara skyldiga att genomföra kontroller vid misstanke om att passagerare reser utan giltiga idhandlingar.

Ett antal privatpersoner som pendlar över den svensk-danska gränsen i Öresund har ansökt om skadestånd hos Justitiekanslern i Sverige på grund av de id-kontroller som utförs vid transporter till Sverige och anfört att de är olagliga. Justitiekanslern har i nuläget inte fattat beslut i något sådant ärende.

\subsection{Færre asylansøgere i Norden}

EU's aftale med Tyrkiet, lukningen af den vestlige Balkanrute og grænsekontroller i flere europæiske lande har gjort det sværere for migranter at komme igennem Europa og nå frem til Norden. I løbet af de første ni måneder af 2016 har Finland, Norge og Sverige modtaget mellem $69 \%$ og $84 \%$ færre asylansøgere end samme periode sidste år. Danmark har haft et mindre fald end Finland, Norge og Sverige - 29 \% januaraugust sammenlignet med samme periode 2015.

Som det eneste land har Island noteret et stigende antal asylansøgere i løbet af 2016 - antallet er steget med $155 \%$ i perioden januar-august sammenlignet med samme periode for et år siden. Antallet af asylansøgere på Island har ligget mellem 40 og 70 asylansøgere per måned siden efteråret 2015.

Det faldende antal asylansøgere har ledt til nedjustering af prognoserne for antal asylansøgere. FNs flygtingehøjkommissariat UNHCR har nedjusteret sin prognose for hvor mange flygtninge og migranter, der forventes at komme til EU fra Tyrkiet i 2016, fra en million til 250.000 . 
Migrationsverket nedjusterede i juli sin prognose for antal flygtninge og migranter, der søger asyl i Sverige til 30.000-50.000 for 2016. I februar var forventningen at mellem 70.000 og 140.000 ville søge asyl i Sverige i 2016.

Den danske regering præsenterede i august et nyt udlændingeudspil i forbindelse med præsentationen af den økonomiske helhedsplan, 2025-planen, der indeholder en nedskrevet prognose for antal asylansøgere i 2016. Nu forventes 10.000 at søge asyl i Danmark i 2016, mens det tidligere var forventet, at 25.000 ville søge asyl.

Tabel 1: Antal asylansøgere i de nordiske lande*

\begin{tabular}{|c|c|c|c|c|c|}
\hline & Denmark & Finland & Sweden & Iceland & Norway \\
\hline 2015Mo1 & 647 & 326 & 4.896 & 15 & 595 \\
\hline $2015 \mathrm{Mo2}$ & 476 & 326 & 4.040 & 15 & 530 \\
\hline $2015 \mathrm{Mo3}$ & 465 & 357 & 4.117 & 10 & 535 \\
\hline $2015 \mathrm{Mo} 4$ & 564 & 345 & 3.917 & 20 & 580 \\
\hline $2015 \mathrm{Mo5}$ & 914 & 518 & $5 \cdot 376$ & 5 & 1.225 \\
\hline 2015Mo6 & 1.077 & 770 & 6.619 & 20 & 1.145 \\
\hline 2015Mo7 & 1.063 & 1.479 & 8.065 & 20 & 1.395 \\
\hline 2015Mo8 & 1.813 & 2.894 & 11.746 & 45 & 2.330 \\
\hline 2015Mog & 2.757 & 10.836 & 24.307 & 60 & 4.935 \\
\hline $2015 \mathrm{M}_{10}$ & 3.694 & 7.058 & 39.196 & 55 & 8.660 \\
\hline $2015 \mathrm{M}_{11}$ & 5104 & 5.732 & 36.726 & 45 & 8.155 \\
\hline $2015 \mathrm{M}_{12}$ & 2742 & 1.835 & 13.872 & 35 & 1.030 \\
\hline 2015 & 21.316 & 32.476 & 162.877 & 345 & 31.115 \\
\hline $2016 \mathrm{Mo1}$ & 1.645 & 1.018 & 4.166 & 50 & 413 \\
\hline $2016 \mathrm{Mo2}$ & 917 & 858 & 2.731 & 41 & 277 \\
\hline $2016 \mathrm{Mo} 3$ & 471 & 359 & 2.245 & 46 & 298 \\
\hline $2016 \mathrm{Mo} 4$ & 400 & 390 & 2.048 & 42 & 228 \\
\hline $2016 \mathrm{Mo5}$ & 384 & 342 & 2.064 & 56 & 227 \\
\hline $2016 \mathrm{Mo} 6$ & 464 & 350 & 2.112 & 39 & 260 \\
\hline $2016 \mathrm{Mo} 7$ & 404 & 362 & 2.158 & 42 & 264 \\
\hline $2016 \mathrm{Mo8}$ & 284 & 480 & 2.417 & 67 & 295 \\
\hline 2016Mog & .. & 521 & 2.389 &.. & 264 \\
\hline 2016 januar-september & 4.969 & 4.680 & 22.330 & 383 & 2.526 \\
\hline 2015 januar-september & 7.019 & 17.851 & 73.083 & 150 & 13.270 \\
\hline $\begin{array}{l}\text { Andring jan-sept 15/ jan-sept, 16/ jan-aug } \\
\text { 15/ jan-aug } 16\end{array}$ & $-29 \%$ & $-74 \%$ & $-69 \%$ & $155 \%$ & $-81 \%$ \\
\hline
\end{tabular}

Note: * For Danmark og Island sammenlignes jan-aug, da der ved redaktionens slutning ikke forelå statistik for september 2016.

Kilde: Eurostat, nyianmark.dk, Maahanmuuttovirasto, Migrationsverket, Útlendingastofnun. 


\section{Udvalgte grænseovergange i Norden}

Det er første gang siden 1957 at nordiske borgere skal identificere sig når de krydser en grænse mellem to nordiske lande. I flere grænseregioner er der et stort udbytte mellem borgere og virksomheder på begge sider af grænsen og derfor er der udvalgt 11 grænseovergange, som er blevet undersøgt nærmere i forhold til hvilke effekter IDog grænsekontrollen har for borgere, virksomheder og trafikken på tværs af grænsen.

\subsection{Danmark}

Danmark indførte midlertidig grænsekontrol på grænsen mod Tyskland den 4. januar 2016. Kontrollen er forlænget frem til den 12. november.

Politiet fortsætter sin kontrol på grænsen mod Tyskland, men siden den 13. juni har Hjemmeværnet bistået politiet med grænsekontrollen. Siden juli har Hjemmeværnets bistand udgjort 125 helårsværk og politiets indsats 320 helårsværk. Rigspolitiet, Nationalt Udlændingecenter (NUC), oplyser at der har været et højere kontroltryk henover sommeren. Eksempelvis blev 89.583 personer kontrolleret ved grænsen i uge 30 , hvoraf 80 personer blev afvist. I uge 41 blev 67.037 personer kontrolleret og 68 personer blev afvist, hvilket svarer til cirka en promille. Omfanget af indsatsen justeres løbende efter "efterretningsbilledet og den aktuelle situation ved grænsen", oplyser NUC.

I juni oplyste Rigspolitiet at grænsekontrollen gav anledning til en ressourcemæssig prioritering som kunne lede til længere sagsbehandlingstid i sager med mindre alvorlig kriminalitet. I oktober henviser Rigspolitiet til samme svar fra juni og der er således ikke nogen ændring angående dette.

Der har været debat om grænsekontrollen i Danmark, hvor blandt andet Dansk Folkeparti ønsker at gøre grænsekontrollen permanent og kræver desuden en folkeafstemning om hvorvidt Danmark skal træde ud af Schengen- samarbejdet. Der er en opinion for den midlertidige grænsekontrol i Danmark - $66 \%$ var for at forlænge grænsekontrollen ved en måling i maj som Norstat har lavet for Altinget - og regeringen har meldt ud at man vil forlænge grænsekontrollen efter 12. november. 


\subsubsection{Rødby og Gedser}

Rødby havn er et af dansk politis fokusområder for grænsekontrol. I efteråret 2015 kom der mange flygtninge med færgen fra Tyskland til Rødby og flere hundredevis gik under et par dage i september 2015 på motorvejen fra Rødby for at komme videre til Sverige til fods.

Siden Danmark har indført midlertidig grænsekontrol, kontrolleres alle passagerer efter de har forladt færgen i Rødby, uanset om det er i bil, i tog eller gående. Kontrollen gennemføres af politiet med assistance fra Hjemmeværnet.

I foråret mente de aktører som Øresundsinstituttet talte med, at der ikke var nogle større gener af grænsekontrollen. Den blev beskrevet som hurtig og effektiv og uden betydning for trafikken eller regionens udvikling. Dog var nogle af aktørerne bekymret for at det på lang sigt ville kunne skade regionen og hæmme udviklingen af den fælles dansk-tyske Femern-region.

Ifølge rederiet Scandlines giver grænsekontrollen ikke anledning til større problemer eftersom den gennemføres, når passagererne forlader færgen. Men der har været nogle episoder i sommerperioden, som er højsæson for rederiet, hvor der har været så lang kø ved grænsekontrollen, at det ikke har været muligt at tømme og fylde færgen i Gedser på de 15 minutter, som rederiet ellers har afsat i havn. Rederiet mener at årsagen har været en kombination af nye medarbejdere hos politiet og Hjemmeværnet og at der i Gedser er et begrænset opmarchområde og dermed ikke plads til så mange ventende biler. Ifølge Scandlines kommunikationsdirektør Anette Ustrup Svendsen, aftager problemet i takt med at højsæsonen klinger af. I øvrigt har Scandlines ikke oplevet nogle større problemer med grænsekontrollen og der har ikke været nogle negative reaktioner fra passagererne.

Antal køretøjer på ruten Rødby-Puttgarden ligger på samme niveau 1. halvår 2016 som 1. halvår 2015, mens antal passagerer er faldet 2,3 \%. På Gedser-Rostock ruten, der er en langt mindre rute end Rødby-Puttgarden, er såvel antal køretøjer som antal passagerer steget $9 \%$ i 1. halvår 2016 sammenlignet med 1. halvår 2015, hvilket forklares ved vækst i ferieperioderne og i januar 2016.

Statistikken for antallet af togrejsende fra Tyskland til Danmark kan ikke splittes op på de to grænseovergange, der har togtrafik, Rødby-Puttgarden og den dansktyske landegrænse. Det totale antal togrejsende mellem Tyskland og Danmark er faldet $10 \%$ i 1. halvår 2016, mens den landsdækkende togtrafik (InterCity-tog) er faldet langt mindre $(2,6 \%)$ i samme periode ifølge Danmarks Statistik.

Overnatningsstatistikken for Vest- og Sydsjælland viser at antallet af svenske hotel- og feriehusovernatninger er faldet med 1,7 \% i perioden januar til august 2016 sammenlignet med 2015 , mens antallet af tyske overnatninger er steget med 4,8 \%. For hele Region Sjælland er antallet af tyske hotel- og feriehusovernatninger steget 
med $5,9 \%$, mens de svenske overnatninger er uforandrede. Den danske grænsekontrol ser således ikke ud til at forårsage færre tyske gæster på Sjælland, men derimod kan der muligvis ses en effekt af ID- og grænsekontrollen mellem Sverige og Danmark - det er dog en lille mindskning og antallet af svenske overnatninger i Region Sjælland svinger historisk meget. Desuden er antallet af svenske overnatninger på hotel steget med $10 \%$ i Region Sjælland.

\section{Fakta om grænseovergang Rødby-Puttgarden/Gedser-Rostock}

\section{Forbindelser}

Scandlines har en færgerute som tager biler, tog og gående mellem Rødby og Puttgarden i Tyskland. Færgen afgår to gange i timen. Derudover afgår der en færgeforbindelse mellem Gedser og Rostock hver anden time.

\section{Antal rejsende}

Der rejser i gennemsnit 16.819 personer og 5.547 biler over Femern Bælt hver dag (2015-tal). Dagligt rejser i gennemsnit 2.170 personer med tog mellem Danmark og Tyskland over landegrænsen og via Rødby-Puttgarden i alt.

\section{Sådan fungerer grænsekontrollen}

Den 4. januar blev der indført midlertidig grænsekontrol i Rødby havn. Der ankommer 48 færger i døgnet til Rødby havn. Når færgerne lægger til kontrolleres alle køretøjer i bilfeltet og gående ved landgang når de har forladt færgen. Der udføres ekstra kontrol af udvalgte biler. Toget holdes tilbage og politi går ombord for at kontrollere alle passagerer. Ifølge Scandlines medfører det ikke nogen forsinkelser eftersom kontrollen først gennemføres når passagerne har forladt færgen og færgen kan, som tidligere, sejle igen efter 15 minutter i havn. Politiet kontrollerer alle passagerers legitimation og hvis en person mangler legitimation og vil søge asyl, kan personen gøre det. Vil personen ikke søge asyl, afvises denne og føres tilbage til Tyskland. Alle rejsende skal medbringe nationalt id og om nødvendigt visum. Da danskerne ikke har et nationalt id-kort, skal de medbringe pas. I Gedser havn er der stikprøvevis kontrol.

\section{Effekter af grænsekontrol}

Der opgives at ikke være nogle større effekter for trafikken, erhvervslivet eller turismen, men en bekymring for hvilke signaler en fortsat grænsekontrol kan sende i forhold til udviklingen af Femern Bælt regionen. Der har ikke været nogen ændring i løbet af sommerperioden. Omkring 10 gange har der været lang kø ved tømning af færgen i Gedser, men rederiet Scandlines oplyser i øvrigt at grænsekontrollen ikke har påvirket sommertrafikken. 


\subsubsection{Sønderjylland-Schleswig}

Dansk politi har fokus på grænsekontrol på de tre største grænseovergange ved Padborg, Kruså og Frøslev samt toget fra Flensborg til Padborg. På øvrige grænseovergange udføres stikprøvekontrol flere gange i døgnet af såkaldte sektorpatruljer. Ud over bil- og togtrafik er der også rutelagte busser over grænsen.

I foråret mente de aktører som Øresundsinstituttet talte med at den danske grænsekontrol ikke ledte til nogle større problemer.

I løbet af sommeren har der været kødannelse ved motorvejen som effekt af grænsekontrollen, vejarbejde og sommertrafikken. Også ved tyskernes efterårsferie i starten af oktober 2016, rapporterede TV Syd om lange køer ved grænsen for trafik i nordgående retning på motorvejen $\mathrm{A} 7$.

Både DSB, Arriva og Aktiv Bus som kører henholdsvis tog og busstrækninger over grænsen, har fået forsinkelser på grund af grænsekontrollen. Arriva, som har en toglinje fra Esbjerg til Niebüll, oplever en stikprøvekontrol cirka en gang om måneden ved Tønder station og det leder til 5-10 minutters forsinkelse. DSB oplyser i deres halvårsrapport at rettidigheden for togtrafik fra Tyskland er dårligere på grund af grænsekontrollen. Aktiv Bus oplever også en del forsinkelser på motorvejen i nordgående retning på vej til Kruså, som skyldes en kombination af grænsekontrol og vejarbejde, som forårsagede at to vejbaner og en busbane blev reduceret til én vejbane for alle trafikanter med lange køer til følge. Aktiv Bus oplyser dog at forsinkelserne ikke har været alt for alvorlige og de har kunnet holde køreplanen. Køer opstår især på lørdage, hvor feriehus-turisterne skal til sommerhusene i Danmark. Det samme billede giver Peter Hansen, leder af Regionskontoret for det dansk-tyske regionsamarbejde SønderjyllandSchleswig.

"Generelt er der mere kø på motorvejen, men særligt om lørdagen hvor der er sengeskifte. Det har givet anledning til en del trafikkaos på motorvejen, men også ved grænseovergangen ved Kruså, hvor der er en landevej. Det er også den vej som anbefales via trafikradioen, men eftersom der er vejarbejde, så har der også været lange køer der." siger Peter Hansen.

Køerne på motorvejen kan være 3-8 kilometer lange, siger han. Men udover at folk kan blive irriterede, hvis de for eksempel skal til et arrangement om lørdagen og så ikke kan komme i tid, tror Peter Hansen ikke at grænsekontrollen har nogen større påvirkning.

"Der er ikke nogen der stopper sine ferieplaner på grund af grænsekontrollen og køerne" siger

Peter Hansen. 
Rigspolitiet oplyser at der har været "køtendenser" i weekender og ferieperioden, men at politiet løbende har tilrettelagt kontroludførelsen i forhold til Vejdirektoratets rapporter og åbnet ekstra vejspor ved forventet højere trafiktryk.

De tyske turister lejer ofte sommerhuse, når de er i Danmark, men feriehusstatistikken fra Danmarks Statistik er endnu ikke opdateret på regional niveau. På nationalt niveau er antallet af tyske feriehusovernatninger steget med $7,2 \%$. Overordnet for alle overnatningsformer er antallet af tyske overnatninger i Danmark steget med 5,9 \% i januar til august 2016 sammenlignet med samme periode sidste år. I Region Syddanmark er de faldet med 1,4\%. Eftersom feriehusstatistikken ikke er klar på regionalt niveau kan den ikke sige noget om sommerhusudlejningen i Syddanmark. Der er færre tyske overnatninger på campingpladser, lystbådehavne og i feriecentre, mens de er steget på hoteller og vandrerhjem. På et mere lokalt niveau er antallet af tyske hotel- og feriecenterovernatninger steget med 0,2 \% i Landsdel Sydjylland.

De fire borgmestre i de sønderjyske Tønder, Aabenraa, Haderslev og Sønderborg har udtalt til TV Syd, at de anser at grænsekontrollen ikke længere er nødvendig og ønsker derfor at regeringen ophæver kontrollen. Ud over at borgmestrene anser, at den er overflødig, mener de, at den ikke er god for det grænseoverskridende samarbejde. Derudover har der været reaktioner fra tysk side, over at Hjemmeværnet bistår politiet med grænsekontrolsopgaven, eftersom det ser ud som soldater ved grænsen.

\section{Fakta om grænseovergang Sønderjylland-Schleswig}

Forbindelser

Der ankommer tog fra Tyskland til Padborg og Tønder station. Fra Flensborg station kan man 9 gange dagligt tage toget til Danmark via Padborg og desuden findes et nattog fra Hamborg til Danmark. Denne rute trafikeres af DSB i et samarbejde med DB.

Arriva kører i et samarbejde med Norddeutsche Eisenbahngesellschaft Niebüll GmbH tog fra Esbjerg i Danmark via Tønder til Niebüll i Tyskland. Ruten har 11 daglige afgange på hverdage i sommerhalvåret. Busselskabet Sydtrafik kører rute 110 mellem Sønderborg i Danmark og Flensburg i Tyskland og krydser landegrænsen ved Kruså. Ruten har 16-18 daglige afgange. Tyske Aktiv Bus kører hvert 20. minut på mellem Flensburg og Kruså.

Antal rejsende

Omkring 48.000 køretøjer krydsede dagligt grænsen i 2012-2013. Flest (16.000 køretøjer) passerer grænseovergangen ved Frøslev, der ligger på motorvej E45/A7. Omkring 14.000 køretøjer passerer den dansk-tyske landegrænse ved Kruså og tredjestørst er Padborg med omkring 10.000 køretøjer per dag, viser tal fra Region Syddanmark.

Omkring 13.900 pendler fra Tyskland til Sønderjylland og omkring 650 pendler den modsatte vej. Disse pendlertal er ikke direkte sammenlignelige med pendlertal for de nordiske grænseregioner, da opgørelsesmetoden ikke er den samme. 
Busselskabet Sydtrafik har gennemsnitligt færre end 20 personer dagligt (130 personer per uge) med på ruten, når den krydser den dansk-tyske grænse. Hovedparten af de rejsende er studerende eller folk, der ikke har bil. Aktiv Bus har i gennemsnit 100 rejsende med over grænsen per dag. Lidt færre, 50-6o personer, på søn- og helligdage.

Sådan gennemføres grænsekontrollen

Den 4. januar blev der indført midlertidig grænsekontrol på den dansk-tyske grænse. Det er en overvågningsbaseret stikprøvekontrol på de tre største grænseovergange ved Padborg, Kruså og Frøslev samt i toget fra Flensborg til Padborg. På øvrige grænseovergange udføres stikprøvekontrol flere gange i døgnet. Ventetiden i forbindelse med grænsekontrollen er typisk på 3-5 minutter, men kan give længere køtid på op til 15 minutter. Især i ferieperioder er der pres på grænsen. Ventetiden betegnes af interviewpersonerne som uproblematisk. For togtrafikken stiger politiet på toget på stationen og gennemfører grænsekontrollen.

\section{Effekter af grænsekontrol}

Der opgives at ikke være nogle større effekter af den indførte midlertidige kontrol. Der er sket en håndfuld ulykker i forbindelse med kødannelse til grænsekontrol. Hvis der bliver indført transportansvar er der risiko for at de linjelagte busser over grænsen bliver indstillet.

Der er ingen ændring siden juni. Køerne har været lange i løbet af sommeren, men har ikke påvirket turismen i øvrigt. Togtrafikken oplever forsinkelser i forbindelse med grænsekontrollen, men ikke så meget at køreplaner er blevet ændret.

\subsubsection{Rønne-Ystad}

Bornholm er direkte berørt af både dansk og svensk grænsekontrol. Rejsende som kommer til Bornholm med færge fra tyske Sassnitz kontrolleres i en stikprøvekontrol af dansk politi i Rønne. Rejsende fra Bornholm som tager til det øvrige Danmark gennem Skåne, med færgen fra Rønne til Ystad og med bil, tog eller bus videre, skal igennem en stikprøvekontrol udført af rederiet ved ombordstigning på færgen. På hjemvejen skal bornholmerne, hvis de er med Øresundstoget, igennem en ID-kontrol på stationen i Københavns lufthavn samt en grænsekontrol i Hyllie. Er de med bil kontrolleres de af svensk politi ved Øresundsbroen eller i færgehavnen i Helsingborg. Der er ikke svensk grænsekontrol i Ystad havn.

I sommerperioden har der, ifølge rederiet Færgen, ikke været nogle større problemer i forhold til at screene passagererne når de går ombord på færgen til Ystad. Det har ikke været nogle reaktioner eller forsinkelser, opgiver Færgens pressekoordinator Annette Timmermann.

Et forslag om indførelse af et nationalt ID-kort behandles i øjeblikket i Folketinget. Dette vil blandt andet gøre det lettere for bornholmerne, når de skal vise ID ved 
den svenske ID- og grænsekontrol ved Kastrup og Hyllie/Lernacken i og med at de så ikke behøver et pas.

Grænse- og ID-kontrollen har ikke påvirket antal rejsende eller turismen. Den overnatningsstatistik fra Danmarks Statistik som er tilgængelig på landsdelsniveau er kun for hoteller og feriecentre og på Bornholm er antallet af overnatninger steget med $5,9 \%$. De svenske overnatninger er faldet med $0,8 \%$ og de tyske er steget med $7,4 \%$.

Antal overførte køretøjer på ruten Rønne-Ystad er steget 0,6 \% i 1. halvår $2016 \mathrm{i}$ forhold til samme periode året forinden, mens der har været 0,3 \% vækst i antal passagerer, viser statistik fra Færgen. Samtidig er passagerantallet på ruten Rønne-Køge steget med $14,5 \%$.

\section{Fakta om grænseovergang Rønne-Ystad}

Forbindelser

Rederiet Færgen har færgeruter som tager biler og gående mellem Rønne og Ystad, Rønne og Køge samt Rønne og Sassnitz i Tyskland. Færgen har 6 afgange om dagen til Ystad i vintersæsonen og 9 afgange i sommersæson samt 1 afgang om dagen til Køge og 1-3 afgange om dagen til Sassnitz afhængig af sæson. (Derudover afgår der en færgeforbindelse mellem Nexø og Kolobrzeg en gang om ugen) Fra Bornholms Lufthavn flyver DAT 11 gange om dagen til Københavns Lufthavn og i sommersæsonen er der også fly til charterdestinationer.

\section{Antal rejsende}

Der rejser i gennemsnit 3.644 personer og 857 personbiler over Rønne-Ystad hver dag (2015-tal 1.330.021 passagerer og 312.833 biler i 2015). På ruten Rønne-Køge er det hovedsagligt lastbiler 28.759 lastbiler og 58.709 passagerer i 2015. Rønne-Sassnitz havde 101.283 passagerer i 2015, 29.214 personbiler, 187 lastbiler og 212 busser.

Rønne-Ystad har cirka go \% af de rejsende fra Bornholm til resten af Danmark, ifølge Bornholms Regionkommune.

\section{Sådan gennemføres kontrollen på Rønne-Ystad}

Da Sverige indførte grænsekontrol den 12. november var Ystad havn ikke et af fokusområderne. Men Bornholmerne er berørt af den svenske grænsekontrol, hvis de rejser via Skåne til resten af Danmark og dermed skal igennem en kontrol på hjemvejen ved betalingsanlægget ved Øresundsbroen, i toget ved Hyllie eller på færgen mellem Helsingør og Helsingborg. Rederiet Færgen har indført en kontrol på ruten Rønne-Ystad og til at starte med blev alle passagerer bedt om at vise ID, men nu foregår kontrollen som en screening, hvilket indebærer at passagerne overvåges ved indgang til færgen.

Ifølge rederiet stoppes biler eller personer for ID-kontrol eksempelvis hvis de ikke ligner nordiske borgere eller har udenlandske nummerplader.

Sådan gennemføres den danske grænsekontrol på Rønne-Sassnitz 
I sommerhalvåret sejler rederiet Færgen også mellem Rønne og Sassnitz i Tyskland. På denne rute er der dansk grænsekontrol. Dansk politi har en stikprøvekontrol i Rønne og er til stede ved alle ankomster, hvor de kontrollerer ved landgang og i bilfeltet. Der kommer flest passagerer i bil på denne rute og de der bliver udvalgt for kontrol, henvises til en særskilt bane. Rederiet Færgen kontrollerer også passagernes ID inden afgang i Sassnitz. Stena-Line udfører kontrollen på vegne af Færgen, hvor de fotograferer pas, når passagerne sidder i bilen og venter på at køre ombord. Alle passagerer på denne rute skal også registrere personoplysninger ved billetkøb. Det er et krav fra de tyske myndigheder.

\section{Effekter af græensekontrol}

Dder opgives at ikke være nogle større effekter af den indførte midlertidige kontrol for trafikken fra Sassnitz. Derimod fremhæver flere af de som Øresundsinstituttet har talt med på Bornholm, at de bliver påvirket negativt af grænse- og ID-kontrollen ved Øresund eftersom det skaber endnu et transitproblem og forlænger rejsetiden til resten af Danmark via Skåne. Ingen ændring siden juni angående trafikken og sommertrafikken mellem Ystad og Rønne har ikke været påvirket af kontrollerne. Folketinget behandler et forslag om et dansk ID-kort, som ville kunne bruges i stedet for pas.

\section{$2.2 \quad$ Finland}

Vid gränsövergångarna mot Sverige införde Finland så kallad effektiviserad tullkontroll mellan den 22 september 2015 och den 29 februari 2016. Samtidigt införde Polisen och Gränsbevakningsväsendet förstärkt övervakning av utlänningar, med särskild fokus på den svensk-finska gränsen. Även den avslutades under våren.

I april stängdes Finlands två nordligaste gränsövergångar mot Ryssland (RajaJooseppi och Salla) för andra nationaliteter än finländare, ryssar och vitryssar, enligt en överenskommelse med Ryssland. Begränsningen gällde i sex månader, till den 6 oktober. Under den korta tid som gått sedan dess har Gränsbevakningsväsendet inte noterat någon exceptionell situation vid gränsövergångarna, uppger Kimmo Elomaa, vice avdelningschef för gräns- och sjöavdelningen vid Staben för Gränsbevakningsväsendet.

Antalet asylsökande till Finland via de inre Schengengränserna har legat på en stabil låg nivå sedan i maj.

Finland utreder för närvarande hur Gränsbevakningsväsendets uppgifter kan utvidgas och vilka lagändringar som är nödvändiga för att förbereda gränskontrollen för så kallade hybridhot - hot som uppstår snabbt, så som terrorism. Samtidigt undersöks om det finns behov av att införa ett transportörsansvar för transportföretag som korsar de inre Schengengränserna. Utredningen ska vara klar under 2017. 


\subsubsection{Haparanda-Torneå}

Den effektiviserade tullkontrollen, som infördes vid gränsövergångarna mellan Sverige och Finland under hösten och vintern 2015-2016, innebar att trafiken mellan svenska Haparanda och finländska Torneå bevakades, att resenärer tillfrågades om sina ärenden och skåpbilar genomsöktes. Orsaken till att åtgärderna infördes var det stora antal flyktingar som kom via Sverige till Torneå under hösten 2015.

Övervakningen av utlänningar återgick under våren till normal nivå och den effektiviserade tullkontrollen avslutades alltså i februari 2016.

Sedan den förra rapporten ID- og grænsekontroller i Norden. Effekter af ID- og grænsekontroller $i$ et nordisk perspektiv har inget nytt skett. Läget är tillbaka till det normala i Haparanda-Torneå, rapporterar såväl tullen i Torneå och Gränsbevakningsväsendet som de gränsregionala organisationerna.

\section{Fakta om gränspassagen Haparanda-Torneå}

\section{Förbindelser}

Haparanda och Torneå skiljs åt av Torne älv. Större delen av Torneå ligger öster om älven, men stadens centrum är placerat på en ö, som till vissa delar är sammanväxt med den västra älvkanten. Tre vägar passerar gränsen: $E_{4}$ :an, en vanlig gata och en mindre granngata. Det finns också en järnvägsförbindelse där enbart godstrafik passerar. Haparanda och Torneå har ett gemensamt resecentrum i Haparanda. Lokaltrafikens ringlinje, med avgångar cirka en gång i timmen under dagtid) passerar genom båda städerna. Flera finländska regionalbusslinjer har sin ändhållplats vid resecentrum i Haparanda. En del turer med Länstrafiken i Norrbotten har också sin ändhållplats i Torneå.

Antal resenärer

Drygt 14 miljoner personer passerar årligen gränsen, eller cirka 40000 på en dag.

\section{Så utförs kontrollen}

Ingen gränskontroll har införts i Finland, men förstärkt övervakning av utlänningar och effektiv tullbevakning infördes under hösten och vintern 2015/2016. Bevakningen gick till så att tullen fanns vid de tre gränspassagerna mellan Haparanda och Torneå 24 timmar om dygnet. Under de första två veckorna stoppade Tullen fordon och pratade med passagerarna. Baserat på samtalet fick en del av fordonen och passagerarna genomgå tullkontroll. Alla bussar som passerade från Haparanda till Torneå stoppades under vintern. Eftersom städerna har ett gemensamt resecentrum i Haparanda handlade det såväl om lokalbussarna (Ringlinjen) i Haparanda-Torneå som regionalbussar på båda sidor gränsen. Normalt krävdes inte id-handlingar för att passera gränsen. Stoppet tog oftast någon eller några minuter och köerna rapporteras ha varit korta, då de uppstod.

En bit från gränsen fanns Gränsbevakningsväsendet, som tog över om det fanns några asylsökande eller andra personer som saknade korrekta id-handlingar eller inte hade rätt att passera in till Finland.

Även polisen fanns på plats. Deras uppgift var framför allt att arrangera transport av asylsökande 
till registreringscentret och att registrera dem där. När antalet asylsökande minskade något under hösten fick polisen också tid att förhöra dem och utreda deras ärenden. Vid registreringscentret var även andra aktörer, som finländska Röda Korset, involverade.

Effekter av kontrollen

Kontrollerna påverkade inte det dagliga livet i någon större utsträckning, utöver att många upplevde att gränsen blev mentalt mer påtaglig i början. Det har inte varit några kontroller sedan slutet av februari.

\subsubsection{Helsingfors}

I början av 2016 införde Finnlines, som driver färjetrafik mellan tyska Travemünde och Helsingfors, visumkontroll för personer som kommer frăn länder med visumkrav för inresa i Finland. Det skedde efter att finländska myndigheter påmint rederierna om deras förpliktelser avseende kontroll av passagerarnas giltiga resedokument. Finnlines upplevde i våras inte att de nya kraven inneburit några större problem för rederiet.

Både Viking Line och Tallink Silja, som kör varsin färjelinje mellan Stockholm och Helsingfors, meddelade i våras att de utför stickprovskontroller av id-handlingar bland passagerarna, precis som de tidigare gjort. Tallink Silja intensifierade id-kontrollerna under en period i början av sommaren 2015, då rederiet märkte att antalet personer utan id-handlingar ökade på färjan, men kunde sedan gå tillbaka till det normala.

Enligt Finnlines har sommartrafiken flutit på som normalt och inget nytt har skett sedan i våras.

\section{Fakta om gränspassagen via Helsingfors hamn}

Förbindelser

- Helsingfors-Stockholm (7 avgångar/vecka med Tallink Silja, 7 avgångar/vecka med Viking Line och 2 avgångar/vecka med St. Peter Line).

- Helsingfors-Tallin (6 avgångar/dag med Tallink Silja, 3 avgångar/dag med Viking Line och 14 avgångar/vecka med Eckerö Line).

- Helsingfors-Mariehamn (7 avgångar/vecka med Tallink Silja och 7 avgångar per vecka med Viking Line).

- Helsingfors-Travemünde (6 avgångar/vecka med Finnlines).

- Helsingfors-Sankt Petersburg (3 avgångar/vecka med St. Peter Line).

Antal resenärer: Totalt 11,5 miljoner passagerare på alla linjer under 2015, enligt statistik från Helsingfors hamn. 
Så utförs kontrollen

Finland har inte infört gränskontroll, men rederierna införde visum-kontroll på färjorna från Tyskland i december 2015

Innan ombordstigning på färjan från Travemünde till Helsingfors kontrollerar Finnlines att resenärer, från länder med visumkrav för att besöka Finland, har korrekta resehandlingar. För övriga resenärer gäller vanlig passkontroll, något som Finnlines hade redan tidigare.

Både Viking Line och Tallink Silja, som kör varsin färjelinje mellan Stockholm och Helsingfors, utför stickprovskontroller av id-handlingar bland passagerarna, precis som de tidigare gjort. Tallink Silja införde tätare id-kontroller under en period i början av sommaren 2015, då rederiet märkte att antalet personer utan id-handlingar ökade på färjan. I och med det minskade antalet direkt, uppger bolagets operativa chef Hans Friberg.

Effekter av kontrollen

Inga större effekter, uppger Finnlines som trafikerar linjen Helsingfors- Travemünde. Sommartrafiken har inte påverkats av id-kontrollerna.

\subsection{Norge}

Den 26 november 2015 införde Norge gränskontroll på färjorna som ankommer till landet från Danmark, Sverige och Tyskland. Dessutom åligger det rederierna att kontrollera id-handlingar och eventuella visum till Norge, med hot om böter om informationen eller kontrollerna brister. Kontrollen är förlängd till den 11 november 2016.

Rederierna har trots tidigare farhågor inte upplevt några större problem under sommaren på grund av gräns- och id-kontrollerna.

Norge har också intensifierat sin territorialkontroll sedan den 22 september 2015, i närheten av de inre Schengengränserna, särskilt i fylkena Østfold och Hedmark. Det gäller fortfarande.

Norge har en yttre Schengen-gräns mot Ryssland och har beslutat att bygga ett 270 meter långt och tre meter högt stålstängsel vid Storskogens gränsstation mot Ryssland. Enligt nyhetsbyrån Reuters kom 5500 personer in i Norge via den rutten i fjol. 


\subsubsection{Svinesund, Morokulien och Örje}

Sedan september i fjol har Norge intensifierat sin territorialkontroll, framför allt i områdena Østfold och Hedmark där de stora gränsövergångarna mot Sverige ligger. Under hösten innebar det bland annat en tidvis tätare närvaro vid gränsen, även om Norge inte infört någon tillfällig inre gränskontroll för landgränsen. Redan i juni upplevde många av dem som Øresundsinstituttet talade med att läget var tillbaka till det normala igen.

Inte mycket har förändrats sedan dess. Den intensifierade territorialkontrollen kvarstår, uppger Maren Vaagan, seniorrådgivare för Politidirektoratet.

Den lokala polisens situation, som var något ansträngd under förra hösten, är nu som vanligt igen, uppger Merete C. Beck, sektionschef vid utlänningssektionen i Østfold.

Lokala samarbetsorganisationer som Svinesundskommittén och Grensetjänsten har inte heller märkt av några kontroller utöver det vanliga.

\footnotetext{
Fakta om gränspassagen Svinesund

Förbindelser

E6:an genom Strömstad, samt järnväg som bland annat trafikeras med passagerartåg av det norska statliga tågbolaget NSB.

Antal resenärer: $14.000-15.000$ fordon per dygn

Så utförs kontrollen

Det är ingen gränskontroll på gränsen mellan Sverige och Norge, men intensifierad territorialkontroll sedan 22 september 2015, vilket betyder att polisen varit mer närvarande än vanligt och med särskilt fokus på Østfold och Hedmark. Det innebär att polisen kan stanna en person och kräva legitimation när det finns anledning att tro att personen är en utländsk medborgare samt att "tid, plats och situation ger anledning till en sådan kontroll", enligt Maren Vaagan, seniorrådgivare på Grense- och utlendingssektjonen.

Effekter av kontrollen

Polisen fick under hösten prioritera ner en del av sina övriga arbetsuppgifter och det rådde viss osäkerhet bland resenärer om vilka krav på id-handlingar som gäller. Läget har inte förändrats sedan juni.
}

Fakta om gränspassagerna Eda/Morokulien och Ørje, samt övriga norsk-svenska gränsen

Förbindelser

Ett 40-tal vägpassager, varav två av de mest trafikerade är E18 vid Ørje och svenska riksväg 62/norska riksvei 2 vid Eda/Morokulien. Även järnväg mellan Kiruna och Narvik. 


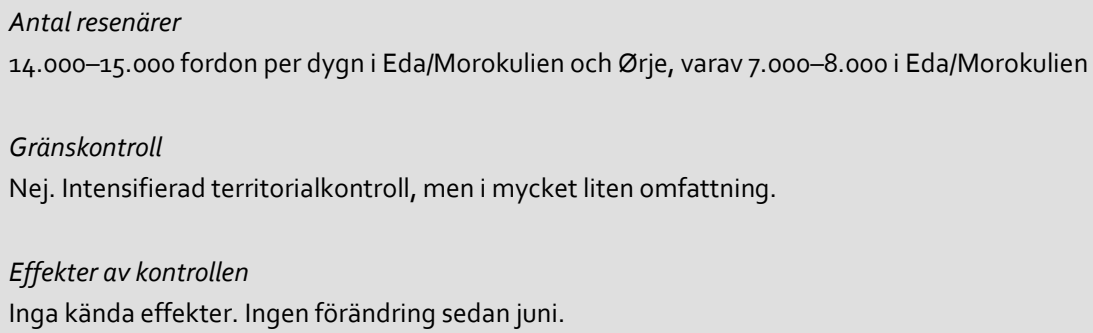

\subsubsection{Oslo Hamn}

När Øresundsinstituttet intervjuade rederierna som anlöper Oslo hamn under våren 2016 såg de inte några större negativa konsekvenser av id-kontrollen, men några var lite oroliga för att färjorna inte skulle hinna tömmas och vända i tid för tillbakaresan, särskilt under högsäsongen. Därutöver innebar det extra kostnader för rederierna, bland annat Stena Line som hyrde in extra personal för att genomföra kontrollerna.

Rederierna Fjordline och Stena Line uppger att det under sommarperioden inte har varit några problem till följd av id- och gränskontrollen.

Stena Line behöver inte längre hyra in extrapersonal för att kontrollera idhandlingar. De har beslutat att enbart godta pass och nationella id-kort eftersom de kan avläsas maskinellt och därmed gör kontrollen smidigare. I Norge godtar rederiet även id-kort med bild utställt av bankerna vilket gör kontrollen lite mer besvärlig, enligt Lars Pålsson på Stena Line.

Kontrollen i Norge kräver överhuvudtaget mer manuell hantering än den i Sverige och kan ge anledning till merkostnader, menar Lars Pålsson. Men i övrigt ser han inga problem.

Den inre gränskontrollen vid hamnarna i Norge genomförs som stickprovskontroller av resenärer med färjorna från Sverige, Danmark och Tyskland. Polisens urval baseras på riskanalyser och profilering av de resande. För polisen som utfört gränskontrollerna har sommarsäsongen med många turister varit krävande, uppger Maren Vaagan, seniorrådgivare vid Politidirektoratet.

Polisen har inte upptäckt att asylsökande gömt sig under lastbilar, men kan inte heller utesluta att det sker. 


\section{Fakta om gränspassagen via Oslo hamn}

Förbindelser

Oslo-Frederikshavn med 7 avgångar/vecka trafikeras av Stena Line. Oslo-København med 7 avgångar/vecka trafikeras av DFDS Seaways. Oslo-Kiel med 7 avgångar/vecka trafikeras av Color Line. (Langesund-Hirtshals med 7 avgångar/vecka trafikeras av Fjord Line.)

Antal resenärer

2,5 miljoner resenärer per år med färjorna till Danmark och Tyskland, samt kryssningsfartyg.

\section{Så utförs kontrollen}

Gränskontroll infördes den 26 november i norska hamnar. Innan ombordstigning på en färja på väg mot Norge kontrollerar rederiet att samtliga passagerare har giltiga id-handlingar som stämmer med namnet på biljetten. Giltiga id-handlingar är pass eller annat giltigt resedokument, uppger norska Politiet. För passagerare från länder där visumkrav gäller för inresa i Norge är rederierna skyldiga att även kontrollera att personerna har visum. Nordiska medborgare rekommenderas att ha med pass eller nationellt id-kort, annars måste de kunna göra det troligt att de just är nordiska medborgare på annat sätt, till exempel genom någon annan typ av id-handlingar.

För rederierna gäller att de hotas av böter om informationen eller den fysiska kontrollen inte är tillräckligt bra, så att personer utan de rätta id-handlingarna kommer med till Norge.

I hamnen i Oslo utför sedan polisen en gränskontroll av passagerarna. Polisen har rätt att visitera personer för att undersöka om de gömmer id-handlingar. De kan också söka igenom bilar eller andra fordon för att avgöra om någon gömmer sig där. Polisen får stöd av tullen med att genomföra kontrollen, uppger Maren Vaagan, seniorrådgivare på Grense- og utlendingsseksjonen, Politidirektoratet.

\section{Effekter av kontrollen}

Ekonomiska effekter för vissa rederier, på grund av att de fått hyra in personal för att sköta idkontrollerna. Även problem med administration, att incheckningen tar längre tid och stress med att hinna vända båtarna i hamnen. För passagerarna är effekterna minimala, såvitt de har sina idhandlingar med sig. Ingen förändring har skett sedan juni. Sommartrafiken har inte påverkats.

\section{$2.4 \quad$ Sverige}

Sverige införde tillfällig gränskontroll den 12 november 2015, utökade den 21 november kraven på id-kontroll av passagerare på färjor som går till Sverige och den 4 januari 2016 infördes dessutom ett transportörsansvar för den kollektiva trafiken från Danmark till Sverige.

I samband med att id-kontrollerna i juni förlängdes med med fyra månader till den 4 november 2016 gav den svenska regeringen berörda myndigheter i uppdrag att re- 
dogöra för såväl positiva som negativa effekter av id-kontrollerna. Materialet från de berörda myndigheterna överlämnades till Justitiedepartementet den 23 september och utgör ett underlag till beslutet om huruvida id-kontrollerna ska förlängas.

Gränskontrollerna har förlängts till den 11 november.

\subsection{1 Öresundsbron fordonstrafiken}

Personer som reser över Öresundbron via motorvägen kontrolleras av svensk polis vid betalningsanläggningen vid Lernacken. Som infrastrukturägare omfattas inte Øresundsbro Konsortiet av transportörsansvaret. Det gör däremot bussoperatörerna med reguljär trafik över Öresund, som därmed måste kontrollera passagerarnas id-handlingar.

Öresundsbrons betalningsanläggning är en av de platser som den svenska polisen prioriterar högst vad gäller gränskontroll. Mellan 95 och $100 \%$ av resenärerna kontrolleras, enligt Polisens uppgifter från oktober 2016. Under sommaren har köer på högst tio minuter uppstått i gränskontrollen, uppger Øresundsbro Konsortiet. Det innebär att läget är ungefär detsamma som i våras, då Øresundsinstituttet gjorde den förra analysen.

Personbilstrafiken över Öresundsbron har ökat under hela 2016, men under våren låg stigningen på samma nivå som den gjorde under 2015. Under sommaren tilltog personbilstrafiken dock ytterligare och i september passerade $8 \%$ fler bilar över Öresundsbron än under samma månad i fjol. Det är med stor marginal den största ökningen under en septembermånad sedan 2008. Øresundsbro Konsortiet noterar desutom en ökning specifikt i bilpendlingen på $8 \%$ i september, varav hälften bedöms bero på att tågpendlare byter till bil på grund av gräns- och id-kontrollerna.

Samtidigt har tågtrafiken med Öresundståg minskat med $12 \%$ till och med augusti i år (läs mer under rubriken Öresundsbron tågtrafiken). De enkätundersökningar som gjorts av Øresundsinstituttet och Karin Winter vid KTH bekräftar att många pendlare över sundet valt att byta från tåg till bil på grund av id- och gränskontrollerna för tågresenärer. Dessutom har antalet svenskar som tar bilen till Köpenhamns flygplats i Kastrup ökat och antalet som tar tåget minskat.

Busstrafiken över Öresundsbron ökade i stort med $13 \%$ under juli-september 2016 jämfört med samma period i fjol. Det beror till viss del på att danska arbetsgivare hyrt in bussar för sina anställda för att de ska slippa de olägenheter med tågbyten och längre restid som uppstått på grund av id-kontrollerna. Däremot rapporterar de reguljära busstransportörerna ingen ökning av antalet resande. Nettbuss Travel har tvärtom sett en minskning av antalet resenärer till och från Köpenhamn med 5,2 \% under januariaugusti i år jämfört med samma period i fjol. I våras uppgav bussbolaget att de var be- 
redda att lägga ner linjen till Köpenhamn, något de fortfarande överväger, bland annat på grund av oron för att förlora sitt trafiktillstånd om de gör två misstag i id-kontrollen.

"Förutom detta så medför de extra kostnader som vi får i och med den inhyrda kontrollfirman att vi inte tjänar pengar på sträckan. Något som också kan tilläggas är att vi får rätt dåligt rykte hos våra resenärer när vi inte låter dem att åka med trots att dem har giltig biljett. Norges största tidning VG har bland annat skrivit en artikel om hur vi lämnar kvar norska ungdomar i Danmark", uppger Robert Nyberg, vd för Nettbuss Travel AB.

\section{Fakta om grænsekontrol på Øresundsbrons vejde}

Antal køretøjer

Der passerer i gennemsnit 19.300 køretøjer over Øresundsbron per dag (2015).

\section{Sådan gennemføres grænsekontrollen}

Midlertidig grænsekontrol blev indført den 12. november 2015. Det er en partiel kontrol. Politi/paskontrollanter kontrollerer ID-papirer for de rejsende med busser, biler og lastbiler som kører igennem betalingsanlægget ved Øresundsbron. Det er tilladt at passere betalingsanlægget med maksimalt $30 \mathrm{~km} / \mathrm{t}$ ved anvendelse af en elektronisk sender (BroBizz). At i stedet holde stille for at vise ID er derfor ikke et større trafikalt problem. Uden for myldretiden glider trafikken, men der kan være ventetid på op til 10 minutter i myldretiden for at komme igennem betalingsanlægget. Grænsekontrollen er dog ikke fuldstændig, men partiel, og i tilfælde med meget trafik, kontrolleres en mindre andel af køretøjerne end i de mere stille perioder.

\section{Effekter af grænsekontrol}

Uden for myldretiden glider trafikken, men der kan være ventetid på op til cirka 10 minutter i myldretiden for at komme igennem betalingsanlægget. Ingen ændring siden juni. Sommertrafikken har ifølge Øresundsbro Konsortiet ikke været påvirket af grænsekontrollerne mere end med maksimalt 10 minutters kø ved meget trafik.

\subsection{2 Öresundsbron tågtrafiken}

Precis som i juni innebär id-kontrollen att resenärer med Öresundståg från Danmark till Sverige måste kliva av tåget vid Köpenhamns flygplats, ta sig till en annan perrong där de visar sina id-handlingar, för att sedan åter stiga på tåget. Bytestiden är nio minuter (för det mesta) - eller 29 minuter om det är långa köer. SJ gör sin kontroll på Köpenhamns Hovedbanegård och tåget stannar sedan inte förrän vid Hyllie station $\mathrm{i}$ Malmö.

För gränskontrollen vid Hyllie station stannar tåget i genomsnitt nio minuter för att poliserna eller gränskontrollanterna ska hinna genomföra kontrollen. Under somma- 
ren har det varit glesare mellan kontrollerna - enligt polisens presstalesperson EwaGun Westford kontrolleras $25-35 \%$ av resenärerna.

För att tåget ska komma rätt i tidtabellen står det därefter stilla vid Malmö C i cirka tolv minuter innan det kör vidare.

Id-kontrollerna har främst drabbat tågresenärer från Danmark till Sverige genom att restiden ökat, tågbytena blivit fler och tågavgångarna färre, trängseln har ökat och konsekvenserna av förseningarna blivit mer omfattande. Även de som reser internt $\mathrm{i}$ Skåne påverkas av ökad trängsel på Öresundstågen eftersom tågen vid vissa tillfällen består av färre tågsätt än tidigare då tågmaterielet utnyttjas till det yttersta, bland annat på grund av trafikupplägget på stationen vid Köpenhamns flygplats i Kastrup.

Restiden med Öresundståg mellan Köpenhamns huvudbangård och Malmö centralstation har ökat från 35 minuter till 55 eller 75 minuter. Tidsskillnaden beror på om man hinner med nästa tåg vid tågbytet (som orsakas av id-kontrollen) och idkontrollen vid Köpenhamns flygplats. Det är id-kontrollen tillsammans med gränskontrollen på Hyllie som orsakar den förlängda restiden på upp till 75 minuter.

Åtta tågavgångar från Sverige till Danmark har försvunnit under rusningstiden mellan klockan 06.00 och 09.00 och tio avgångar mellan Danmark och Sverige mellan klockan 15.00 och 18.00 . Totalt har antalet sittplatser per timme blivit 1.700 färre $i$ rusningstrafiken på grund av den lägre frekvensen i avgångar. För närvarande finns det 2100 platser per timme, mot tidigare 3.800. Detta bidrar ytterligare till trängseln under rusningstid - $\mathrm{i}$ båda riktningar - och att reseupplevelsen försämras.

SJ, som gör sin id-kontroll på Huvudbangården, kör alltså tågen direkt till Malmö C med endast ett kort stopp för gränskontroll vid Hyllie station. Resenärerna behöver därmed inte byta tåg vid Kastrup och sparar en halvtimmes restid. Priset för resan är visserligen lägre hos Öresundstog än SJ, som dessutom bara har tre avgångar per dygn, men antalet kortväga resenärer med SJ mellan Köpenhamn och Malmö ökade ändå med $44 \%$ mellan mars och augusti 2016 jämfört med 2015, uppger bolagets affärschef Maria Rosendahl. Totalt sett minskade dock antalet resenärer med SJ över Öresund.

Punktligheten för Öresundstågen mellan Danmark och Sverige ligger för 2016 på ungefär samma nivå som under 2015. Under fem av årets nio första månader var punktligheten sämre under 2016, allra sämst i juni då bara 77,6 \% av tågen mot Sverige passerade mätpunkten vid Pepparholm i tid. Det bör dock noteras att tidtabellerna är justerade för det förändrade trafikupplägget som beror på id- och gränskontrollerna. Resan tar därför längre tid än den gjorde för ett år sedan, utan att det räknas som en försening. De förseningar som inträffar påverkar också resenärerna i högre grad eftersom antalet avgångar och kapaciteten på tågen är mindre. 
Resandeminskning för tågen

Försämringarna i tågtrafiken resulterade i en resandeminskning för Öresundstågen med $12 \%$ under januari-augusti 2016 jämfört med samma period 2015. Till det kan läggas en utebliven ökning av antalet resenärer på 5 \%, som DSB och Skånetrafiken tidigare räknat med.

För SJ, som på grund av id-kontrollerna dragit ner på antalet avgångar från fem till tre per dygn, har antalet resenärer minskat med 20-25\%.

Resandeminskningen beror delvis på att många pendlare valt att resa på annat vis, bland annat med bil (läs mer under rubriken Öresund fordonstrafiken), men även att vissa pendlare har fått möjlighet att arbeta hemifrån en eller ett par dagar i veckan. Skånetrafikens sålda periodkort för sträckan över Öresundsbron minskade med $5,5 \%$ under januari-augusti i år jämfört med samma period i fjol. Försäljningen av periodkort har minskat varje månad sedan april och under augusti och september var minskningen åtta respektive 11 \%, uppger Skånetrafiken. Men även det privata resandet har minskat. Skånetrafiken uppger att antalet fritidsresor över bron har minskat kraftigt och att de har gått 23 miljoner SEK under budget på området under juliseptember.

\section{Kostnader för operatörerna}

Kostnaderna för id-kontrollen, som DSB och Skånetrafiken delar på, ligger på omkring 4,5 miljoner DKK, motsvarande 5,8 miljoner SEK, per månad. Det gäller sedan i april då DSB slopade fotograferingen av resenärernas id-handlingar och genomförde en ny upphandling för utförandet av id-kontrollen.

Enligt SJ är kostnaderna för id-kontrollen till säkerhetsbolag och ökad intern arbetsbelastning närmare tio miljoner SEK per år.

De ekonomiska konsekvenserna för bussbolagen som kör mellan Danmark och Sverige skiljer sig åt. Vissa låter de egna chaufförerna stå för id-kontrollen och har därför inga extrautgifter. Andra har lagt ut id-kontrollen på en leverantör. Nettbuss Travel har dessutom behövt göra en systemanpassning på sin hemsida för att uppmärksamma kunderna på kravet att ha giltig en id-handling med sig på resan, i samband med biljettköpet som sker på nätet. Robert Nyberg, vd för Nettbuss Travel AB, uppger att företaget under januari-augusti haft kostnader på 700.000 SEK för genomförandet av id-kontrollen.

\section{Tillgängligheten till Köpenhamn flygplats}

På grund av trafikomläggningen som orsakats av id-kontrollen går det inte längre några direkttåg till flygplatsen från stationer som ligger längre bort i Danmark än Hovedbanegården, med undantag för tågen från Nivå. De som reser från andra stat- 
ioner inom Köpenhamn eller från orter på Själland, Fyn eller Jylland måste byta tåg för att komma till Köpenhamns flygplats i Kastrup.

Till följd av detta har andelen resenärer från Danmark som tar tåget till Köpenhamns flygplats i Kastrup minskat från 25-16 \% under januari-september 2016 jämfört med samma period 2015, enligt flygplatsens egen statistik. Andelen resenärer från Sverige som tar tåget har minskat från 80-74 \%. Flygresenärer från Danmark väljer i stället i högre grad metron och flygresenärer från Sverige bilen för att ta sig till och från flygplatsen.

Ett problem för resenärer från Sverige till flygplatsen är att tågen från Sverige som är mellan sex och tio minuter försenade inte stannar utan kör direkt till nästa station, Tårnby, där passagerarna får gå av och ta ett annat tåg tillbaka till flygplatsen. Det beräknas ta cirka 15-35 minuter extra i restid för resenärer till flygplatsen. Enligt uppgifter från DSB som presenterats av Danmarks transportminister Hans Christian Schmidt (V) har Öresundstågen från Sverige kört förbi Kastrup utan att stanna 417 gånger under årets åtta första månader.

"Den væsentligste forandring i de seneste måneder set med vore øjne er, at flere og flere tog kører udenom CPH Station. Det gælder især tog fra Sverige mod Danmark. Det rammer naturligvis dem, der skal ud og flyve, men det rammer også de mange svenskere, der arbejder i eller omkring lufthavnen og som benytter toget til at pendle", säger Kasper Hyllested, presschef vid Köpenhamns flygplats.

Det går dock inte att utläsa ur trafikstatistiken för flygplatsen att antalet flygresenärer från Sverige som väljer Köpenhamns flygplats skulle ha påverkats av de olägenheter i tågtrafiken som orsakats av id- och gränskontrollerna.

Initiativ för att underlätta för resenärerna

Inget nytt har framkommit sedan juni i försöken att sammanföra gräns- och idkontrollerna till en gemensam kontroll.

Däremot undersöker DSB i samarbete med Banedanmark och Köpenhamns flygplats möjligheterna att gå tillbaka till tiominutersdrift av Öresundstågen i rusningstid. Detta skulle ske genom ett upplägg där id-kontrollerna genomförs på samma perrong som tågen ankommer till och avgår från. Det skulle vara möjligt om perrongen delades av på mitten. I september inledde DSB realtidstester av möjliga alternativ för en förändrad id-kontroll på spår 1 på Köpenhamns flygplats. Ett beslut kan väntas i månadsskiftet oktober-november och själva förändringen skulle tidigast kunna ske runt årsskiftet. 


\section{Säkerhetsmässiga incidenter}

Sedan id-kontrollerna infördes har det till och med den 2 oktober 2016 vid 135 tillfällen inträffat att människor har gått i Öresundstunneln eller i Kastrup på väg dit. När det finns gående i tunneln stoppas all trafik för att förhindra olyckor.

Antalet incidenter med personer i eller nära tunneln ökade kraftigt under sommaren och under perioden 22 juni till 15 augusti skedde i genomsnitt 5,7 incidenter per vecka. Än så länge har det inte skett någon olycka, men personer i eller nära tunneln skapar emellanåt mycket stora problem för tågtrafiken med inställda tåg och mycket trängsel på tågen när trafiken åter är i gång.

Under de sista veckorna i september minskade dock antalet incidenter, uppger Sanna Holmqvist, pressansvarig på Øresundsbro Konsortiet.

\section{Regionale effekter af rejsetidsforlængelsen med Øresundstog}

Effekterne på det øresundsregionale arbejds- og boligmarked af den forlængede rejsetid med Øresundstoget er siden offentliggørelsen af rapporten ID- og grænsekontroller i Norden. Effekter af ID- og grænsekontroller i et nordisk perspektiv fra Nordisk Ministerråd blevet beskrevet i Øresundsinstituttets rapport Det fælles arbejdsmarked $i$ Greater Copenhagen krymper samt i Länsstyrelsen Skånes rapport, Utvärdering av effekter av tillämpningen av förordning om vissa identitetskontroller. Effekterne er blevet beskrevet gennem:

- $\quad$ tilgængelighedskort, der viser hvor mange færre arbejdspladser det er mulig at nå med 1 times rejsetid over Øresund

- en opfølgende spørgeskemaundersøgelse blandt togpendlere over Øresund

- en rundspørge til 10 arbejdsgivere i Greater Copenhagen.

Med åbningen af Øresundsbron i 2000 påbegyndte en integrationsproces mellem den danske og svenske side med det politiske mål, støttet af såvel regionale som nationale politikere, om et fælles arbejds- og boligmarked. En forudsætning for denne integrationsproces var den rejsetidsforkortelse, øgede tilgængelighed og øgede kapacitet som Øresundsbron gav anledning til. Med den nuværende rejsetidsforlængelse for Øresundstogene samt den mindskede kapacitet som følge af ID- og grænsekontrollerne mindskes det fælles dansk-svenske arbejdsmarked betydeligt.

322.000 færre arbejdspladser kan nås på en time fra Malmö C Med kollektiv trafik kan man i dag nå 322.000 færre arbejdspladser i Danmark fra Malmö C og 193.000 færre fra Lund med en times rejsetid sammenlignet med inden ID- og grænsekontrollerne blev indført. Det svarer til, at man fra Malmö C kun kan nå 
6 ud af 10 danske arbejdspladser, der tidligere kunne nås med 1 times rejsetid med den kollektive trafik.

Det københavnske arbejdsmarked er stort set uden for rækkevidde fra Lund i dag. Kun Københavns lufthavn og det omkringliggende område kan nås inden for 1 times rejsetid med tog og bus. Beregninger er udført med Region Skånes tilgængelighedsmodel med tidstabeller for juni 2016 og september/oktober 2015 og skal betragtes som omtrentlige og ikke eksakte beregninger.

Figur 2: Malmö - tilgængelighed med 60 minutters kollektivtrafik

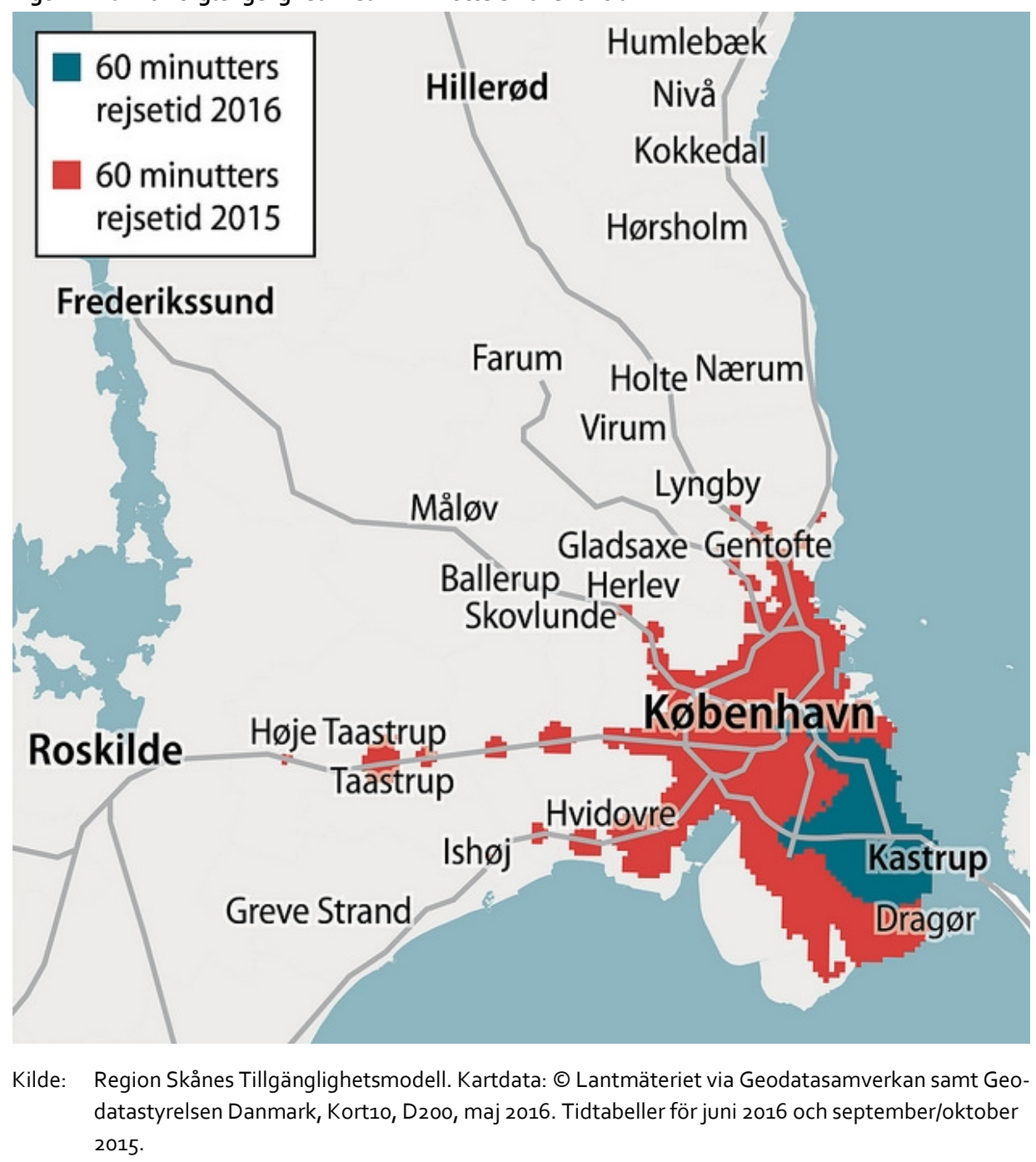


Figur 3: Lund - tilgængelighed med 6o minutters kollektivtrafik

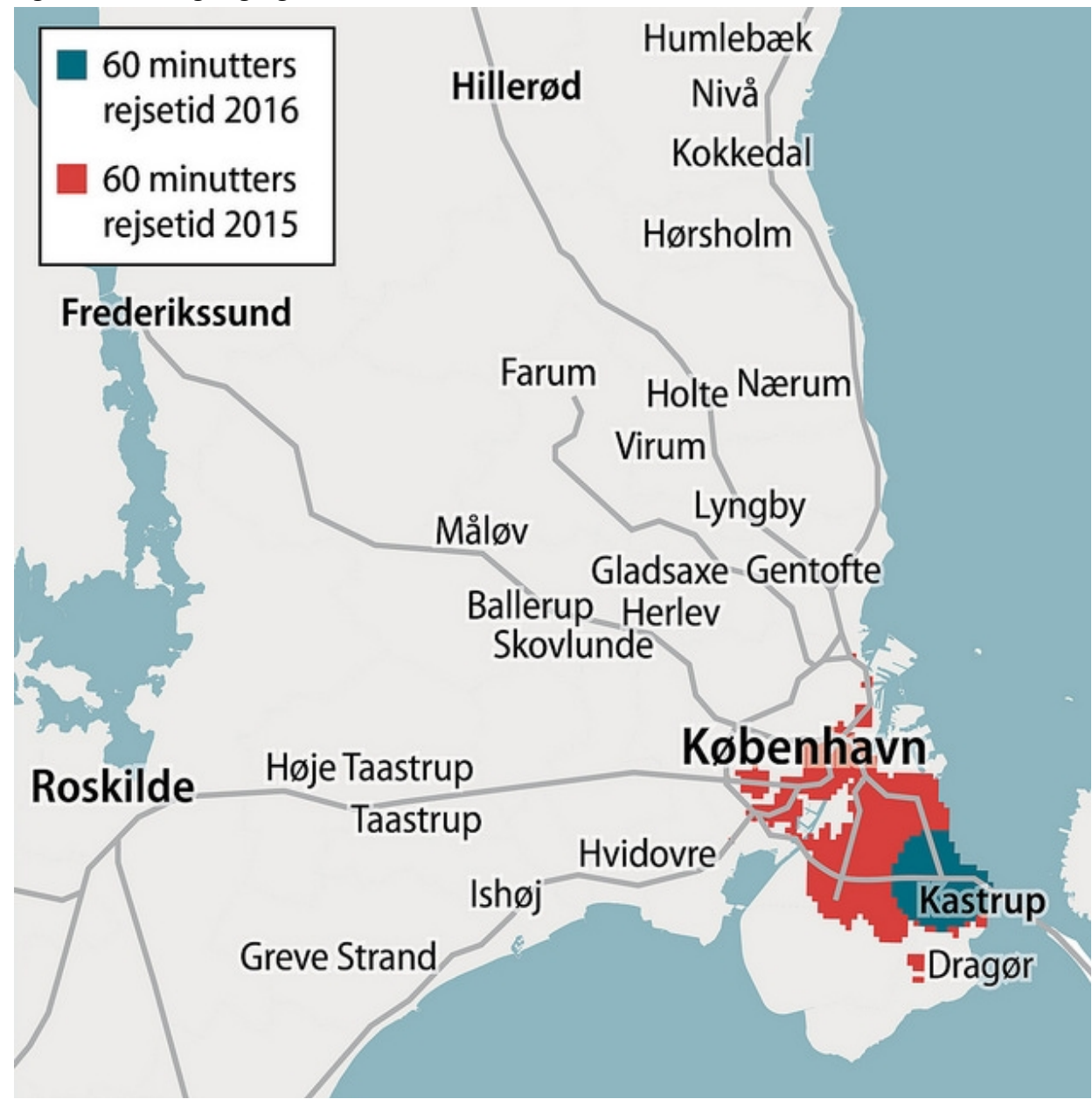

Kilde: Region Skånes Tillgänglighetsmodell. Kartdata: @ Lantmäteriet via Geodatasamverkan samt Geodatastyrelsen Danmark, Kort10, D200, maj 2016. Tidtabeller för juni 2016 och september/oktober 2015.

Många pendlare överväger att söka jobb i hemlandet eller att flytta till arbetslandet

En enkätstudie som genomfördes av Øresundsinstituttet under augusti och september 2016 visar att många pendlare har anpassat sina liv till följd av id-kontrollerna. Hälften av de pendlare som omfattades av studien har förändrat sitt sätt att pendla på ett eller annat sätt. 
Många pendlare överväger att söka eller har börjat söka jobb i hemlandet eller bostad i arbetslandet och enstaka har blivit sjukskrivna eller har sagt upp sig på grund av idkontrollerna:

- $\quad 39 \%$ av respondenterna överväger att söka jobb i hemlandet

- $9 \%$ söker aktivt jobb i hemlandet

- $26 \%$ överväger att flytta till bostad i arbetslandet

- $4 \%$ letar bostad i arbetslandet

- $16 \%$ både söker jobb och letar bostad

- $3 \%$ har fått jobb i hemlandet sedan införandet av id-kontrollerna

- $2 \%$ har flyttat till arbetslandet

- $1 \%$ har blivit uppsagda

- $1 \%$ har blivit sjukskrivna och

- 0,5\% har sagt upp sig på grund av id-kontrollerna

Av de pendlare som svarat har $18 \%$ inga planer på att sluta pendla. Bland dessa är män överrepresenterade. $63 \%$ av de respondenter som inte har planer på att sluta pendla är män, jämfört med $46 \%$ av det totala antalet respondenter. Enkäten har sänts ut via Kystbanens pendlarförenings Facebookgrupp och respondenterna är inte nödvändigtvis representativa för hela pendlargruppen. Det stora antalet svar gör det dock rimligt att anta att avvikelsen inte är alltför stor.

Arbetsgivarna har svårare att rekrytera och behålla medarbetare

Enligt Länsstyrelsen Skåne (2016) visar en enkät som omfattar tio arbetsgivare med anställda som antingen pendlar till arbetet över sundet eller ofta reser till och från Köpenhamns flygplats att det har blivit svårare att rekrytera och behålla medarbetare. Företagen är Ikea och Sony Mobile på den svenska sidan av Öresund, och på den danska Adecco, Copenhagen Malmö Port (CMP), Ferring, Magasin du Nord, Mars Danmark, Novo Nordisk, SOS International och Tivoli.

Resultaten visar att:

- Fem av de åtta danska företagen upplever att de anställda har problem på grund av de försämrade resmöjligheterna med tåg, som beror på id-kontrollerna: Ferring, SOS International, Mars Danmark, Adecco och Magasin du Nord. 
- Hos fyra av de danska arbetsgivarna har mellan två och fem anställda sagt upp sig på grund av id-kontrollerna: Adecco, Ferring, Magasin du Nord och SOS International.

- Fyra av företagen upplever att det blivit svårare att rekrytera ny personal som bor i Sverige. För läkemedelsbolaget Ferring har andelen svenska jobbansökningar minskat från 45 till $30 \%$. Om id-kontrollerna blir långvariga räknar Adecco med att fasa ut rekryteringen av medarbetare som bor i Sverige, såvida det inte handlar om extraordinära experter.

- Flera av arbetsgivarna har infört någon form av åtgärd för att kompensera för de problem som uppstått på grund av id-kontrollerna. Ferring har hyrt in bussar som kör de anställda från Hyllie till Ørestad på morgonen och tillbaka igen på eftermiddagen, till en kostnad av 700000 DKK för 2016. Mars Danmark betalar broavgiften för de anställda som samåker fyra personer i en bil, medan Magasin du Nord justerat medarbetarnas arbets- och mötestider. Företagen uttrycker dock oro för framtiden och menar att de inte i längden kan fortsätta med dessa åtgärder. Då ser de en risk för att ännu fler säger upp sig.

- De tre danska företag som inte har upplevt några problem är Tivoli, där de skiftande arbetstiderna gör att de anställda oftast inte reser under rusningstid; hamnföretaget Copenhagen Malmö Port, vars medarbetare som bor i Sverige redan tidigare pendlade med bil; samt läkemedelsbolaget Novo Nordisk, vars placering i de yttre nordvästra delarna av Köpenhamn antyder att bilpendlande är vanligt bland företagets medarbetare som bor i Sverige.

- Båda Ikea och Sony Mobile upplever att det i och med id-kontrollerna har blivit pressat, osäkert och stökigt att ta sig till och från flygplatsen. Sony Mobile menar att det framöver kan bli aktuellt att förlägga möten till andra orter om alltför mycket tid behöver läggas på praktikaliteter vid inresan till Sverige. Sony Mobile har dessutom fått reaktioner från utländska medarbetare som fått ett dåligt första intryck av Sverige på grund av id- och gränskontrollerna.

- Ikea upplever även att problemen med kortare tåg och förseningar spillt över på den regionala Öresundstågtrafiken i Sverige. Den trängsel som kortare tåg innebär medför bland annat att de drygt 2000 medarbetare som pendlar till kontoret i Älmhult inte längre kan utnyttja tiden på tåget till arbete i samma omfattning som tidigare. Ikea uttrycker oro för de framtida rekryteringsmöjligheterna om id-kontrollerna fortsätter:

"Om man inte åtgärdar de negativa effekterna av kontrollerna så ser vi att vi drabbas negativt. Om de blir långvariga orsakar de svårigheter för oss att rekrytera och behålla medarbetare framför allt till Älmhult. Kompetensförsörjning är avgörande för lkeas fortsatta expansion i södra Sverige." 
Størst negative effekter for kvinder, unge og lavtlønnede

Kvinder, unge og lavtlønnede anvender oftere toget end andre grupper, viser en rejsevaneundersøgelse gennemført efteråret 2015, og rammes dermed i højere udstrækning end andre grupper af de negative effekter af grænse- og ID-kontrollerne. ${ }^{4}$ Samtidig viste forsker Karin Winters undersøgelse blandt goo togpendlere, at de kvindelige togpendlere tenderede til at være ekstra påvirkede af stress. ${ }^{5}$ Informationstjenesten Øresunddirekt bekræfter billedet af at de lavtlønnede påvirkes mest af de negative effekter af grænse- og ID-kontrollerne. Antallet af visninger af jobopslag på Øresunddirekts hjemmeside er faldet for lavtlønsjob i Danmark i perioden januar-september 2016, mens det er steget for højtlønsjob.

Ingen tydelige effekter for turismen

Der er ingen entydige effekter af ID- og grænsekontrol på turismen. Dog tyder det på, at der er en negativ effekt på antallet af overnatninger i nærområdet, dvs. svenske overnatninger i Region Hovedstaden og danske i Skåne, men da mange andre ting påvirker turismen er det svært at konkludere entydigt. Blandt andet er valutaforskellen mellem den danske og svenske krone blevet større. I løbet af sommeren skulle man gennemsnitligt betale 78,5 danske kroner for 100 svenske kroner, hvilket kan påvirke antallet af svenske turister i Danmark negativt, og dermed kan forklare en nedgang i overnatningsstatistikken, men samtidig skulle det kunne påvirke antallet af danske turister i Sverige positivt, hvilket ikke har været tilfældet for Skåne.

Antallet af svenske overnatninger i hele Danmark i perioden januar til august 2016 faldt, ifølge Danmarks Statistik, med 0,2 \% sammenlignet med samme periode sidste år. I Region Hovedstaden er de faldet med $4,3 \%$ og i Region Sjælland var antallet uforandret. På et mere detaljeret regionalt niveau foreligger der kun statistik for hoteller og feriecentre. Her er antallet af svenske overnatninger i landsdel Byen København faldet med $7 \%$.

Antallet af danske overnatninger i hele Sverige i perioden januar til august 2016 er, ifølge $\mathrm{SCB}$, faldet med $7,3 \%$ sammenlignet med samme periode i 2015 , mens de er faldet med 5,1 \% i Skåne og 2,6 \% i Stor-Malmø. Samtidig er antallet af udenlandske overnatninger steget med 8,9 \% i Skåne og 11,4 \% i Malmø i samme periode.

Tourism in Skåne og Malmö Turism gennemførte august/september en spørgeskma- og interviewundersøgelse i turismebranchen i Skåne. Undersøgelsen giver et

\footnotetext{
${ }^{4}$ Region Skåne (2016) Resvaneundersökning Öresund 2015.

5 Winter, Karin (2016). Ny vardag för pendlarna över Öresund. Modtaget fra:http://www.oresundsinstituttet.org/wpcontent/uploads/2016/06/20160610-Analys-ID-kontroller-Karin-Winter-webb.pdf
} 
billede af at antal danske besøgende er uforandret eller er faldet i løbet af $2016 .{ }^{6} 38 \%$ af respondenterne oplyser at danske besøgende udgør en stor eller meget stor andel af deres gæster. Lidt mere end halvdelen af respondenterne i undersøgelsen (53\%) tror ikke at grænsekontrollerne har ført til færre danske gæster, men de respondenter, som har oplyst at antallet danske gæster er faldet kraftigt i løbet af 2016 svarer derimod alle, at de tror at det er på grund af grænse- og ID-kontrollerne (Länsstyrelsen Skåne 2016). Svarsfrekvensen var dog lav.

\section{Fakta om togtrafikken over Øresundsbron}

Antal rejsende

I gennemsnit 32.100 rejsende per dag med Øresundstog over Øresundsbron (2015). Ingen oplysninger om antal rejsende med $\mathrm{X}_{2000}$ og Bornholmertoget.

Sådan gennemføres grænse- og ID-kontrollen

Midlertidig grænsekontrol blev indført den 12. november 2015 og ID-kontrol 4. januar 2016. Rejsende med Øresundstog skal skifte tog i Københavns lufthavn, gå igennem og ned på modsat perron for at gennemgå ID-kontrol og rejse videre mod Sverige. Ved ankomst til Hyllie station gør toget et ophold på cirka 9 minutter for at politi/paskontrollanter kan gennemføre grænsekontrollen.

For IC3-tog til Bornholm og SJ's X2000 gennemføres ID-kontrollen på et afsidesliggende spor på Københavns hovedbanegård, spor 26. Det er ikke muligt at stige af eller på X2000 eller Bornholmertoget i Københavns lufthavn. Ved ankomst til Hyllie station stiger politi/paskontrollanter ombord på toget for at gennemføre grænsekontrol.

\section{Effekter af grænsekontrol}

Rejsetidstidsforlængelser på mellem 12 og 55 minutter. Færre togafgange og mere trængsel i togene. Dårligere togbetjening af Københavns Lufthavn. Faldende antal togrejsende. Stressede og trætte togpendlere, hvor flere overvejer at søge nyt job. Bekymringer for effekterne på længere sigt i form af lavere vækst i Greater Copenhagen/Øresundsregionen.

\footnotetext{
${ }^{6}$ Enkäten skickades ut via e-post till drygt 2100 aktörer inom den skånska besöksnäringen som finns i Tourism in Skånes register. Antalet svar är 145 stycken (svarsfrekvens 6,9\%) så resultatet bör ses som en indikation som tillsammans med övriga källor ger oss en bild av situationen, men respondentbasen är genomgående låg. Dessa enkäter kompletterades sedan med telefonintervjuer med 10 utvalda aktörer som representerar några av de största företagen inom skånsk besöksnäring.
} 


\subsubsection{Helsingör-Helsingborg}

Överfarten Helsingör-Helsingborg har både id- och gränskontroll. Id-kontrollen utförs i Helsingör av rederierna HH Ferries och Sundbusserne. Gränskontrollen genomförs vid ankomsten till Helsingborg av svensk polis, som har $\mathrm{HH}$-överfarten som ett av sina prioriterade områden. 80-90 \% av resenärerna kontrolleras, uppger Ewa-Gun Westford, presstalesperson vid Polismyndigheten i Skåne.

De dubbla kontrollerna har gett upphov till vissa förseningar, framför allt för Sundbusserne, uppgav rederierna i början av sommaren. Då var det oklart hur antalet resande med färjorna påverkats av id- och gränskontrollerna.

Nu visar dock siffror för $\mathrm{HH}$ Ferries att antalet passagerare minskat med 2,1 \% under januari-september 2016 i förhållande till samma period 2015. Antalet personbilar har samtidigt minskat med 2,6\%, men en ökning av antalet bussar och framför allt lastbilar gör att det totala antalet fordon enbart minskat med o,8\%.

Själva restiden med HH Ferries (som drivs under varumärket Scandlines) över Öresund har inte förlängts med mer än ett par minuter på grund av id-kontrollen och kontrollen upplevs som effektiv och smidig, uppgav HH Ferries i juni. Rederiet har inte ändrat tidtabellen. Även i juli månad, som är den månad om året med flest resenärer, avgick färjorna enligt tidsplanen. Sundbusserne har inte heller ändrat i sin tidtabell, men informerade i början av sommaren om att förseningar förekommer betydligt oftare än innan id-kontrollen infördes.

Mellan januari och september 2016 utförde HH Ferries 2,6 miljoner id-kontroller i Helsingör. 8.600 personer nekades att resa med färjorna, varav 176 personer - eller 2 $\%$ - bedöms vara potentiella asylsökande. Den stora merparten var nordiska medborgare som antingen glömt sina id-handlingar eller haft ogiltiga sådana. HH-Ferries utgifter för id-kontrollen uppgår till runt 24 miljoner SEK per år.

Helsingborg påverkas också av det förändrade trafikupplägget över Öresundsbron, som beror på gränskontrollerna vid Hyllie station. Det innebär bland annat att restiden med Öresundståg från Malmöstationerna Triangeln och Hyllie till Helsingborg förlängts med uppemot en kvart.

När Øresundsinstituttet intervjuade turistaktörer i Helsingborg och på Nordsjälland i början av sommaren var de oroliga över hur sommaren skulle gå. Nu visar en enkät- och intervjuundersökning som genomförts av Tourism in Skåne och Malmö Turism under veckorna 34-35 2016, till Länsstyrelsen Skånes rapport Utvärdering av effekter av tillämpningen av förordning om vissa identitetskontroller, att antalet besökare från Danmark är oförändrat eller har minskat något under 2016. Enkäten har dock en låg svarsprocent på 6,9 \% och ger därför ingen representativ bild för turistbranschen som helhet. 
I juni rapporterade transportföretag och polis om incidenter då asylsökande gömt sig under lastbilar innan de körde ombord på färjan till Sverige. Det sker fortfarande regelbundet, uppger Ewa-Gun Westford.

"Vi har särskild uppmärksamhet riktad mot lastbilar och dess underreden. Vi ser regelbundet (om än inte varje dag) att unga män hänger under lastbilarna för att på så sätt ta sig genom kontrollerna. Därför har vi utrustat oss med bättre lampor och samverkar med exempelvis Tull, rederier och lastbilsföretag för att inga individer ska komma ut på de stora vägarna med risk för svåra olyckor som följd", säger hon.

\section{Fakta om gränspassagen Helsingör- Helsingborg}

Forbindelser

Rederiet HH Ferries (Scandlines Helsingør-Helsingborg) sejler mellem Helsingborg og Helsingør med op til 4 afgange i timen i dagtimerne. Derudover sejler Sundbusserne med 8-11 afgange om dagen.

\section{Antal rejsende}

Der rejser i gennemsnit 21.000 personer (både landgang og køretøjer), 4.870 køretøjer mellem Helsingør og Helsingborg hver dag (2015-tal).

Sådan udføres grænse- og ID-kontrol

Sverige indførte grænsekontrol den 12. november 2015 og dette berører færgetrafikken i Helsingborg havn. Til at starte med var det en fuldstændig kontrol af alle passagerer på den svenske side, men fra medio maj er det en stikprøvekontrol. Den 4. januar 2016 blev der indført transportøransvar for færgerne over Øresund og det indebærer, at rederierne skal tjekke om passagererne har gyldig legitimation inden de går ombord på færgen i Helsingør. På HH Ferries udføres ID-kontrollen efter billetkontrol, mens Sundbusserne oftest tjekker billet og ID samtidig. Ifølge HH Ferries har de gennemført 2,6 millioner kontroller mellem januar og september og cirka 8.60o personer er blevet afvist. Heraf var mindre end 180 personer potentielle asylansøgere.

\section{Effekter af grænsekontrol}

Det oplyses at der ikke er nogen større effekter af den indførte midlertidige grænsekontrol og IDkontrol, men rederierne oplever en mindskning i antallet af passagerer. Derudover ses der med bekymring på den ringere togforbindelse til Hyllie og Citytunnelstationen Triangeln samt Københavns Lufthavn. Der er ingen forandring siden juni. Indtil videre ses der ikke nogen tydlige effekter på turismen i regionen. 


\subsubsection{Trelleborgs havn}

Trelleborg havn har været en af de store indgangsporte til Sverige i forhold til flygtningemodtagelsen. Omkring 45.000 flygtninge, deraf mange uledsagede flygtningebørn, kom i perioden september til december 2015 til Trelleborg med færgen. Rederierne anså i foråret at den ID- og grænsekontrol som blev indført for rederierne, som sejler fra Tyskland og Polen til Sverige, krævede ekstra tid og ressourcer. De skal tjekke ID-dokumenter og sammenligne med navnet på billetterne og det stiller krav til personalet som eventuelt skal afvise personer uden godkendt ID. Rederierne oplevede, at det var svært at afgøre hvad som var gyldig ID og at det var tidskrævende og for Stena Line også ressourcekrævende eftersom de havde hyret ekstra personale til opgaven, men i øvrigt havde ID-kontrollen, da Øresundsinstituttet talte med rederierne i foråret, ikke forårsaget nogen videre forsinkelser for færgetrafikken.

Der har heller ikke været nogle negative effekter for sommertrafikken som følge af ID-kontrollen i løbet af sommeren. Stena Line opgiver at eftersom der har været så få flygtninge, så har der ikke været nogle problemer med kontrollen og de ekstra personaleressourcer som de måtte hyre ind i slutningen af 2015 er ikke længere nødvendige. Så kontrollen har ikke givet anledning til øgede omkostninger og forsinkelser i løbet af sommeren.

"Från min horisont kan jag inte se några problem alls. Vi har haft en mycket bra högsäsong och är glada för det. Så jag kan inte se några negativa effekter av id-kontrollen over huvudtaget, " konstaterar Lars Pålsson, säkerhetschef på Stena Line.

Svensk politi oplyser at de kontrollerer omkring 20-40 \% af de rejsende som kommer til Sverige via havnen i Trelleborg.

\section{Fakta om gränspassagen via Trelleborgs Hamn}

Förbindelser

Passagerarfärjor: TT-line och Stena Line har vardera 5 avgångar om dagen till Rostock, Stena Line har 14 avgångar per vecka till Sassnitz, TT-line har 3 avgångar per dag till Travemünde, TT-line har 9 avgångar per vecka och Unity Line 3 avgångar om dagen till polska Swinoujscie.

Antal resenärer

Under 2015 var det 1,7 miljoner passagerare i Trelleborg Hamn (i bilar, tåg och gående).

Så utförs kontrollen

Före ombordstigning kontrollerar färjebolagen att passagerarnas id-handlingar stämmer överens med namnen på biljetterna och upprättar en passagerarlista. Många olika typer av id-handlingar 
godkänns - desamma som är giltiga på de resor mot Sverige som omfattas av transportörsansvaret. Sedan rapporterar rederierna till Skånepolisen hur många asylsökande det finns ombord. Vid hamnen i Trelleborg överlämnas dessa till polisen.

Polisen utför en inre gränskontroll av passagerarna, såväl av dem som kommer med bil eller något annat fordon som av de gående. Hamnen har dock i stort sett inga gående passagerare. Enligt Trelleborgs hamn tar kontrollen bara någon minut extra.

Effekter av kontrollen

Rederierna upplever osäkerhet och konflikter kring vilka id-handlingar som är godkända och har i vissa fall haft extra kostnader på grund av kontrollerna. I övrigt få effekter för resenärer och turism. Ingen förändring har skett sedan juni. Sommartrafiken har inte påverkats.

\subsubsection{Göteborgs hamn}

Två passagerarfärjelinjer anlöper Göteborg: från danska Frederikshavn och tyska Kiel. Båda drivs av rederiet Stena Line, som införde id-kontroller i november. Polisen genomför gränskontroller: på anlöpen från Danmark utförs stickprovskontroller och på anlöpen från Tyskland görs kontroller utifrån den profilering som görs på de passagerarlistor som rederiet presenterar för polisen. När passagerarna anlöper Göteborg görs en fysisk gränskontroll när profileringen visat att det finns misstankar om att det finns medföljande passagerare som inte får komma in i landet. När Øresundsinstituttet intervjuade rederierna under våren 2016 upplevde de inte några större negativa effekter för trafiken, men Stena Line hade extra kostnader för kontrollen och var lite oroliga för sommartrafiken.

Lars Pålsson från Stena Line uppger att det inte varit några problem avseende idoch gränskontrollen sedan antalet flyktingar som kommer till Sverige med färjorna minskade. Sommartrafiken har därmed inte påverkats av id- och gränskontrollen och rederiet har inte behövt anlita någon extrapersonal. Gränspolisen i Region Väst uppger att de efter indikationer på att det åter kom fler personer med färjorna från Tyskland införde en 12 dagar lång tillfällig gränskontroll vid Tysklandsterminalen i september/oktober där alla personer kontrollerades vid avstigning, men polisen har inte haft något att anmärka på under den perioden. Det var även ökad kontroll vid Danmarksterminalen, där det har skett vid ett antal tillfällen att personer håller sig fast under långtradare som kör ombord på färjorna.

I övrigt har det inte skett några förändringar i hur gränskontrollen genomförs i Göteborg. Sammanfattningsvis kan det konstateras att kontrollen inte har påverkat färjetrafiken eller rederierna. Polisen anser att kontrollerna lett till bättre samarbete mellan myndigheterna. 
"Det var bra för oss att få öva, nu fick vi igång samverkan med tullen och kustbevakningen som varit oss behjälpliga," säger Stefan Kristiansson, chef för Gränspolisen Region Väst.

\section{Fakta om gränspassagen via Göteborgs hamn}

Förbindelser

Färjelinjerna Göteborg-Frederikshavn (fyra till sex avgångar per dag) samt Göteborg-Kiel (en avgång om dagen), som båda drivs av Stena Line.

\section{Antal resenärer}

Nära 1,5 miljoner passagerare om året reser till eller från Göteborg med de två färjelinjerna.

Så utförs ID- och gränskontrollen

Stena Line utför id-kontroller innan passagerarna får stiga ombord på färjorna. Rederiet godtar de id-handlingar som enligt den svenska polisen gäller på tåg-, buss- och korta färjelinjer mellan Danmark och Sverige. Barn får lov att åka med utan egna id-handlingar i föräldrars sällskap. Innan de nuvarande id-kontrollerna infördes gjordes bara kontroller när rederiet misstänkte att passagerarlistan inte stämde.

När passagerarna kommer i land i Göteborg utförs emellanåt en gränskontroll. Under vintern var den total, men i maj uppgav polisen att de övergått till så kallad profilering av passagerarlistorna på färjorna från Kiel. Det innebär att polisen studerar passagerarlistorna för varje avgång och bara utför kontroll när de upptäcker att färjan för med sig asylsökande, som antingen själva uppgett att de är det eller där polisen misstänker att det finns någon ombord som inte har rätt att komma in i landet.

Vid Danmarksanlöpen, i Göteborg och i Varberg (med linje till danska Grenå), gör polisen stickprovskontroller. Då och då profilerar de passagerarlistorna och då och då finns de på plats för en fysisk kontroll.

Effekter av kontrollen

Inga större effekter för vanliga resenärer. Ingen förändring har skett sedan juni. Sommartrafiken har inte påverkats. 



\title{
Referencer
}

\author{
Publikationer
}

Andresen, Britt Øresundsinstituttet (2016). Det fælles arbejdsmarked i Greater Copenhagen krymper

Andresen, Britt, Palmehag, Anna, Wiborg, Thea Nordisk ministerråds sekretariat (2016). ID- og grænsekontroller i Norden: Effekter af ID- og grænsekontroller i et nordisk perspektiv

Länsstyrelsen (2016). Utvärdering av effekter av tillämpning av förordning om vissa identitetskontroller

Nordisk ministerråds sekretariat (2016) Rättslig analys av de tillfälliga gräns- och id-kontrollerna i Norden. Promemoria

Svärd, Daniel m.fl. Region Skåne (2016). Resvaneundersökning Öresund 2015

Winter, Karin (2016). Ny vardag för pendlarna över Öresund - konsekvenser av införandet av IDoch gränsekontroller mellan Danmark och Sverige

\section{Webmateriale}

Buhl, Thomas, DR (8.10.2016). Støjberg danner EU-front for at forlænge grænsekontrol Modtaget fra: http://www.dr.dk/nyheder/politik/stoejberg-danner-eu-front-forlaengegraensekontrol

Bundgaard, Mark TV Syd (1.10.2016). Den tyske efterårsferie skabte lørdag lange køer på den tyske motorvej i nordgående retning. Modtaget fra: http://www.tvsyd.dk/artikel/lange-koeersyd-graensen

DR Nyheder (27.6.2016) Danmarks mest benyttede grænseovergange er ikke de mest kontrollerede. Modtaget fra: http://www.dr.dk/nyheder/indland/danmarks-mest-benyttedegraenseovergange-er-ikke-de-mest-kontrollerede

EU kommissionen (6.10.2016). Pressemeddelelse - Sikring af Europas ydre grænser: Åbning af Det Europæiske Agentur for Grænse- og Kystbevogtning Modtaget fra: http://europa.eu/rapid/press-release_IP-16-3281_da.htm

Jakobsen, Hanna, Expressen (28.9.2016). Sverige pressas om gränskontrollerna. Modtaget fra: http://www.expressen.se/nyheter/sverige-pressas-om-granskontrollerna/

Justis- og beredskapsdepartementet, Norge (10.6.2016) : Forlenget grensekontroll på indre Schengen. Modtaget fra: https://www.regjeringen.no/no/aktuelt/forlenget-grensekontroll-paindre-schengen/id2503865/

Kaas, Thomas, Bornholms Tidende (21.9.2016) Nyt bornholmerkort skal bringe os gnidningsfrit gennem Sverige. Modtaget fra: http://tidende.dk/?Id=75869 
Knoph Vigsnæs, Maria VG Nyheter. (3.7.2016) Anders (18) og Peder (18) hadde ikke pass - fikk ikke bli med Nettbus hjem. Modtaget fra

http://www.vg.no/nyheter/innenriks/danmark/anders-18-og-peder-18-hadde-ikke-pass-fikkikke-bli-med-nettbuss-hjem/a/23730218/

Magnusson, Erik (22.9.2016) Sundsresenärer prövar smidigare id-kontroller. Modtaget fra http://www.sydsvenskan.se/2016-09-22/sundsresenarer-provar-smidigare-id-

kontrollerMigrationsverket (25.7.2016) Kontrollåtgärder ger fortsatt effekt på antalet asylsökande till Sverige. Modtaget fra: http://www.migrationsverket.se/Om-

Migrationsverket/Nyhetsarkiv/Nyhetsarkiv-2016/2016-07-25-Kontrollatgarder-ger-fortsatteffekt-pa-antalet-asylsokande-till-Sverige.html

Møller, Ole TV Syd (28.8.2016). Lavere asylantal stopper ikke grænsekontrollen. Modtaget fra: http://www.tvsyd.dk/nyheder/29-08-2016/1930/borgmestre-vil-droppegraensekontrollen?autoplay=1\#player

Nielsen og Nielsen, DR Nyheder (4.9.2016) Borgmestre: Politi-timer spildes ved grænsen. Modtaget fra: http://www.dr.dk/nyheder/politik/borgmestre-politi-timer-spildes-ved-graensen

Nielsen, Nicolas, DR Nyheder (27.6.2016) S og DF: Send flere hjemmeværnsfolk til grænsen. Modtaget fra: http://www.dr.dk/nyheder/indland/s-og-df-send-flere-hjemmevaernsfolk-tilgraensen

Palmehag, Anna News Øresund (9.9.2016). Fler Öresundsresenärer tar X200o över sundet. Modtaget fra: http://www.newsoresund.se/fler-oresundsresenarer-tar-x2000-over-sundet/

Politidirektoratet (5.7.2016) Informasjon om reiser mellom nordiske land. Modtaget fra https://www.politi.no/politidirektoratet/aktuelt/nyhet_16129.xml

Poulsen, Louise Bendix, TV Syd (26.9.2016). Masser af overarbejde til politiet. Modtaget fra: http://www.tvsyd.dk/artikel/masser-af-overarbejde-til-politiet

Scandlines (26.9.2016). Scandlines med fremgang i højsæsonen. Modtaget fra: https://www.scandlines.dk/om-scandlines/presse.aspx

Udlændinge-, integrations- og boligministeriet (3.10.2016). Regeringens nye udlændingeudspil. Modtaget fra http://uibm.dk/nyheder/2016-08/regeringens-nye-udlaendingeudspil

\section{Statistik}

Danmarks Statistik (2016). BANE25: Jernbanetransport af passagerer efter enhed og transporttype. Modtaget fra www.statistikbanken.dk

Danmarks Statistik (2016) TURIST og HOTEL1: Overnatninger og hotelovernatninger efter område, nationalitet og periode. Modtaget fra www.statistikbanken.dk

Dansk Politis resultat af grænsekontrollen. Modtaget fra: https://www.politi.dk/da/aktuelt/presse/graensekontrol/

Maahanmuuttovirasto (2016) Modtaget fra: http://www.migri.fi/information_om_verket/statistik/statistik_over_asyl_och_flyktingar

Migrationsverket (2016) Modtaget fra http://www.migrationsverket.se/OmMigrationsverket/Statistik.html

nyidanmark.dk (2016) Modtaget fra https://www.nyidanmark.dk/da$\mathrm{dk} /$ Statistik/SearchStatistics.htm?searchtype=statistics 
Statistiska Centralbyrån (2016). Inkvarteringsstatistik: gästnätter efter region och hemland. Modtaget fra www.statistikdatabasen.scb.se

Utlendingsdirektoratet (2016) Modtaget fra https://www.udi.no/statistikk-oganalyse/statistikk/asylsoknader-etter-statsborgerskap-og-maned-2016/

Útlendingastofnun (2016) Modtaget fra http://utl.is/index.php/en/about-directorate-ofimmigration/statistics 



\section{Summary}

In autumn and winter 2015/16 border controls, including ID and customs checks, were introduced at internal Nordic borders because of the large numbers of refugees arriving in the Region. This affected the freedom of movement between the countries.

The most noticeable negative impact was felt by people crossing the Øresund by rail. This was still the case in May and June 2016 when the Nordic Council of Ministers was preparing the first report on the effects of the controls - "ID and border controls in the Nordic Region. The effects of ID and border controls in a Nordic perspective." Another outcome was that during the summer, mainly at weekends, kilometre-long queues of vehicles formed at the Danish-German border. Before the summer, shipping companies had expressed a certain degree of concern about how things might develop in the peak season, but border controls caused delays in ferry operations on just a few sailings on a single route, Scandlines Gedser-Rostock. No change was noted at the Swedish-Finnish and Norwegian-Swedish borders.

ID and border controls have had no impact on passenger numbers on ferries from Germany to the Nordic Region, nor on most routes between the Nordic countries. However, the Øresund trains and HH Ferries, which operate between Sweden and Denmark, have seen reductions in the number of travellers, as have passenger trains between Germany and Denmark. The Øresund trains have been hardest hit, with a reduction of 12\% from January to September compared with the same period in 2015 .

One negative effect of border and identity checks on the Øresund trains is that large numbers of people are choosing instead to travel by car. The Øresund Bridge Consortium had already documented increases in bus, taxi and business traffic because of border and ID checks, but in September the numbers commuting by car also rised. The Øresund Bridge road link is the only major traffic route which has experienced high growth, with a 7.7\% rise in the number of vehicles in September.

A series of reports published in recent months focus on how border and ID controls are affecting the joint Danish-Swedish labour market either side of the Øresund:

- For rail travellers, the size of the job market has shrunk considerably, with 322,000 fewer jobs now accessible within an hour by public transport from Malmö Central and 193,000 fewer from Lund. 
- Four out of five of the 400 rail commuters who responded to a questionnaire said they were considering applying for jobs in their home country or moving to the country in which they worked.

- A survey of 10 companies found that Danish employers are finding it harder to recruit and retain employees from Sweden. Some of them compensate their staff, e.g. with more flexi-time or buses to take them home, but they do expext to continue with these measures in the long term. Ikea and Sony Mobile also note problems with poorer access to Copenhagen Airport and greater overcrowding on Øresund trains within Sweden.

The tourism industry has not recorded any significant impact of the imposition of controls. However, there does appear to be a negative impact on overnight stays in Greater Copenhagen and Southern Denmark. The number of overnight stays by Swedes in the Danish Capital Region is down $4.3 \%$; the number of Danes staying overnight in the Swedish Skåne Region is down $5.1 \%$, and the numer of Germans spending the night in Southern Denmark is down 1.4\%.

There has been an increase in the incidence of refugees and migrants risking their lives to cross borders. During the summer, the problem of people approaching or entering the Øresund tunnel worsened, but the number of incidents declined again in September. In the period from 4 January to 2 October 135 people attempted to reach Sweden by this route. Police in both Gothenburg and Helsingborg have found refugees hiding under trucks and report that this is a regular occurrence in Helsingborg.

The practical implementation of ID checks between Denmark and Sweden has demonstrated the inherent contradiction between the traveller's obligation to meet the requirement to present valid ID documents on entering Sweden on the one hand, and the duty of the authorities to assist citizens who do not have valid ID documents with them on the other. The current system is not geared to a situation in which people frequently move back and forth across the border for short periods and therefore can require urgent assistance from officials when this is needed.

According to a judicial review, these temporary border controls are not deemed to be in conflict with the Nordic Passport Union, which entitles citizens of the Region to travel between the countries without a passport or another travel document. 


\section{Bilag 1: Liste over interviewpersoner}

\begin{tabular}{|c|c|c|c|c|}
\hline Grænseområde & Organisation & Fornavn & Efternavn & Titel \\
\hline Rødby & Scandlines & Anette & Ustrup Svendsen & Komminaktionsdirketør \\
\hline $\begin{array}{l}\text { Rødby, Sønderjylland- } \\
\text { Schleswig }\end{array}$ & $\begin{array}{l}\text { Rigspolitiet, Nationalt Udlændinge- } \\
\text { center (NUC) }\end{array}$ & Gry & Ahlefeld-Engel & Chefkonsulent \\
\hline Skåne & Polismyndigheten & Ewa-Gun & Westford & presstalesperson \\
\hline Göteborg & Gränspolisen Region Väst & Stefan & Kristiansson & chef \\
\hline Finland som helhet & Gränsbevakningsväsendet & Kimmo & Elomaa & $\begin{array}{l}\text { vice avdelningschef för gräns- } \\
\text { och sjöavdelningen vid Staben }\end{array}$ \\
\hline Haparanda-Tornio & Tullen Tornio & Kari & Hannu & biträdande chef \\
\hline Haparanda-Tornio & Tornedalsrådet & Peter & Hagström & $\mathrm{vd}$ \\
\hline Haparanda-Tornio & Bothnian Arc & Tuula & Parsiala-Teittinen & kansli \\
\hline Finland/Sverige & Kvarkenrådet & Susanna & Ehrs & Utvecklingschef \\
\hline Helsingfors & Finnlines & Kielo & Vesikko & line manager \\
\hline Øresund & Öresundståg AB & Gunnar & Wulff & vd \\
\hline Øresund & $\varnothing$ resundsbro Konsortiet & Sanna & Holmqvist & pressansvarig \\
\hline Øresund & $\varnothing$ resunddirekt & Karin & Lundvall & verksamhetsansvarig \\
\hline Øresund & $\varnothing$ resunddirekt & Thomas & Steffensen & Sekretariatsleder \\
\hline Oslo & Fjord Line & Rickard & Ternblom & Koncernchef \\
\hline Rønne & Færgen & Annette & Timmermann & Pressekoordinator \\
\hline Sønderjylland-Schleswig & Region Sønderjylland-Schleswig & Peter & Hansen & Leder af regionskontoret \\
\hline Sønderjylland-Schleswig & Aktiv Bus Flensburg GmbH & Bela & Bergemann & $\begin{array}{l}\text { Leiter Tarif \& Strategische } \\
\text { Planung }\end{array}$ \\
\hline Sønderjylland-Schleswig & Arriva & Inge & Poulsen & Kundecenterleder \\
\hline Øresund & Skånetrafiken & Linus & Eriksson & Trafikdirektör \\
\hline Øresund & Copenhagen Airport & Kasper & Hyldested & pressechef \\
\hline Øresund & NEX (Nettbuss Travel) & Mats & Johansson & $\mathrm{vd}$ \\
\hline Øresund & SJ & Maria & Rosendahl & affärschef \\
\hline $\begin{array}{l}\text { Øresund og Sønderjylland- } \\
\text { Schleswig }\end{array}$ & DSB & Niels-Otto & Fisker & pressechef \\
\hline Norsksvenska gränsen & Svinesunds-kommittén & Elsie & Hellström & verksamhetsledare \\
\hline Norsksvenska gränsen & Grensetjänsten Morokulien & Kjell & Olsén & \\
\hline Norsksvenska gränsen & Polisens utlänningsenhet i Østfold & Merete $C$. & Beck & seksjonssjef \\
\hline Norsksvenska gränsen & $\begin{array}{l}\text { Politidirektoratet, Grense- og utlend- } \\
\text { ingsseksjonen, Politifagavdelingen }\end{array}$ & Maren & Vaagan & Seniorrådgiver \\
\hline Västerbotten/Helgeland & MittSkandia & Katti & Lundström & \\
\hline Skibotn & Nordkalottens gränstjänst & Riitta & Leinonen & \\
\hline Trelleborg/ Göteborg/Oslo & Stena Line & Lars & Pålsson & säkerhetschef \\
\hline Trelleborg & TT-line & Eva & Jönsson & Pressansvarig \\
\hline
\end{tabular}


Nordic Council of Ministers

Ved Stranden 18

DK-1061 Copenhagen K

www.norden.org

\section{ID- og grænsekontroller i Norden}

Denna rapport är en uppföljning av rapporten ID- og grænsekontroller i Norden. Effekter af ID- og grænsekontroller i et nordisk perspektiv som offentliggjordes den 4 juli 2016.

Rapporten visar hur situationen har utvecklats under sommaren och hösten 2016 när det gäller de effekter kontrollerna har på mobiliteten, resenärer och ekonomin i de nordiska gränsregionerna. Rapporten fokuserar särskilt på situationen i Öresundsregionen där kontrollerna fortfarande har avsevärda negativa effekter för de resande. Detta gäller i synnerhet för de som arbetspendlar med tåg mellan Sverige och Danmark. Rapporten visar att antalet arbetstillfällen i Danmark som är tillgängliga för arbetspendling från Sverige med kollektivtrafik har reducerats avsevärt och undersökningar bland arbetstagare och arbetsgivare i regionen indikerar att arbetspendlingen kan komma att minska på längre sikt till följd av kontrollerna.

Rapporten har utarbetats av Öresundsinstittutet på uppdrag av Nordiska ministerrådet.

TemaNord 2016:554

ISBN 978-92-893-4757-0 (PRINT)

ISBN 978-92-893-4758-7 (PDF)

ISBN 978-92-893-4759-4 (EPUB)

ISSN 0908-6692

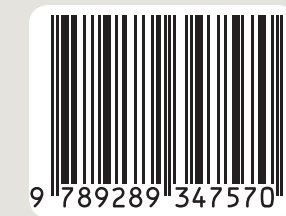

